\title{
Engineering Perspectives and Environmental Life Cycle Optimization to Enhance Aggregate Mining in Vietnam
}

\author{
Petra Schneider ${ }^{1, *(\mathbb{D})}$, Klaus-Dieter Oswald ${ }^{2}$, Wolfgang Riedel ${ }^{2}$, Andreas Meyer ${ }^{1}$, \\ Georg Schiller ${ }^{3}$, Tamara Bimesmeier ${ }^{3}$ (D), Viet Anh Pham Thi ${ }^{4}$ and Long Nguyen Khac ${ }^{5}$ \\ 1 Department for Water, Environment, Civil Engineering and Safety, University of Applied Sciences \\ Magdeburg-Stendal, Breitscheidstraße 2, D-39114 Magdeburg, Germany; andreas.meyer@hs-magdeburg.de \\ 2 C\&E Consulting and Engineering GmbH, Jagdschänkenstrasse 52, D-09117 Chemnitz, Germany; \\ klaus-dieter.oswald@cue-chemnitz.de (K.-D.O.); wolfgangriesa@gmail.com (W.R.) \\ 3 Leibniz Institute of Ecological Urban and Regional Development, Weberplatz 1, D-01217 Dresden, Germany; \\ g.schiller@ioer.de (G.S.); t.bimesmeier@ioer.de (T.B.) \\ 4 Department of Environmental Management, The Faculty of Environmental Sciences, VNU University of \\ Science, 334 Nguyen Trai, Hanoi, Vietnam; phamthivietanh@hus.edu.vn \\ 5 Department of Natural Resources and Environment of Hoa Binh Province, Tran Hung Dao Street, Hoa Binh \\ Province, 350000 Hoa Binh City, Vietnam; klongtnmt@gmail.com \\ * Correspondence: petra.schneider@hs-magdeburg.de; Tel.: +49-391-886-4577
}

Received: 4 December 2017; Accepted: 13 February 2018; Published: 15 February 2018

\begin{abstract}
Cleaner Production (CP) addresses precautionary, site-specific environmental measures to reduce emissions and assess resource efficiency potentials at the point of origin by analyzing operational material and energy flows. The approach is generally based on the criteria quality as well as environmental/occupational health and safety, and promotes their integration. The paper presents options for applying CP to aggregate mining, based on a Life Cycle Assessment (LCA) and illustrated by results from a study of small-scale industrial aggregate mining in Hoa Binh Province (Vietnam). The regulatory framework to limit the impact of mining on the environment is largely comparable to international standards and is suitably enforced. Despite gaining experience through the practical handling of enforcement procedures over the long term, there is still a considerable potential to optimize CP strategies in Vietnam's aggregate mining industry. This is shown by the results of a survey of aggregates mining companies in Hoa Binh Province as well as on-site data collection to determine the technological characteristics of production facilities alongside economic and environmental factors. The assessment of the survey is supported by LCA results for: (a) the existing situation; and (b) the scenario of a merging of companies, undertaken to improve the resource efficiency of the aggregate mining in Hoa Binh. Findings can help implement an integrated approach to foster the sustainable mining of building aggregates.
\end{abstract}

Keywords: cleaner production; aggregate mining; responsible mining strategies; life cycle assessment; best mining practice; material flow analysis; urbanization

\section{Introduction}

\subsection{Background Information}

In the wake of major economic reforms introduced in 1986 (Doi Moi), Vietnam's planned economy has been transformed into a "market economy with a socialist orientation". Achieving steady growth of over $5 \%$, low labor costs and a stable political environment, Vietnam has enjoyed a positive reputation over the past few years as an attractive business location. In 2016, the country's population was 
92.7 million and the nominal GDP US\$197 billion [1]. While the country structures are still heavily agricultural and $70 \%$ of the population lives in rural areas, there is a strong trend of migration towards the urban centers. In 2011, the mining industry generated 11\% of the country's GDP. Due to its economic development, population growth and internal migration, Vietnam is currently enjoying an extraordinary boom in construction, which of course has raised demand for building materials. Figure 1 shows the expected development for the period 2010-2020 of per capita consumption of stone and sand for construction [2].

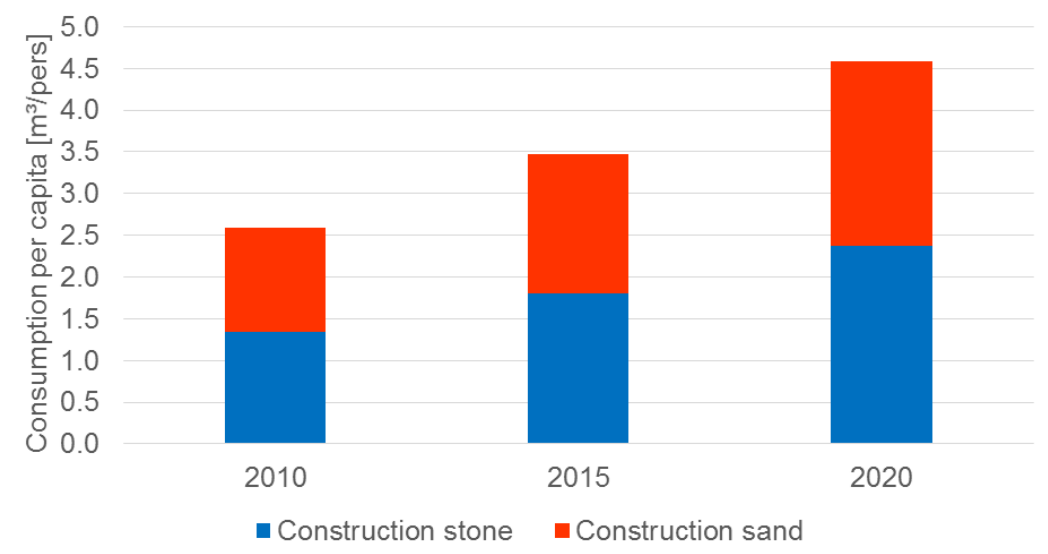

Figure 1. Development of per capita consumption of mineral materials for construction in Vietnam (own calculation based on [2,3]).

Aggregate mining is one of the basic activities for the production of construction materials. Typical quarried materials in Vietnam are limestone, basalt and clay resources [4]. Little construction and demolition waste $(\mathrm{CDW})$ is recycled, as the country is still at an early stage of urbanization. However, with an urbanization rate of $3.4 \%$ per year [1], the proportion of the population living in urban areas is expected to rise from the current figure of $27 \%$ to $45 \%$ by 2020. A forecast for Ho Chi Minh City (HCMC) estimates that the maximum rate of CDW generation will only be reached in 2050 [5]. Nonetheless, pilot activities on the recycling of CDW are already being developed [6,7].

New housing is required for rural migrants pouring into the cities [1]. For this reason, the government has been promoting social housing and the construction of low-cost housing. At the same time, there is a burgeoning market for high value apartments and luxury housing. According to information of the Communist Party in Vietnam, the Hanoi government plans to build 600,000 residential housing units in the satellite town Hoa Lac by the year 2020 [8]. Demand is high in the urban centers, especially Hanoi (which, following a territorial reform, currently has around 7.6 million inhabitants) and HCMC (8.2 million inhabitants) [1]. While socio-economic growth has a positive impact on employment and local incomes, negative repercussions on the environment will be felt for years to come. The effects of Hanoi's growth also affect the hinterland through landscape and land consumption, visual impacts from mining activities on hillsides as well as an increase in the numbers of trucks on the road.

The huge demand in Vietnam for construction materials has fostered unbridled aggregate mining. This topic is investigated by the project "Management of mineral resources extraction in Hoa Binh Province-A contribution to sustainable development in Vietnam (MAREX)". The overall scope of the project is to identify institutional, organizational and economical challenges along the value chain aggregates mining-transport-distribution-construction site-building. Four key subjects are considered in the framework of the MAREX project: (a) environmental monitoring of mining activities according to Vietnamese regulation and beyond; (b) the engineering and environmental aspects of Cleaner Production (CP) technologies in aggregate mining; (c) material flows needed to meet future demand for construction materials; and (d) institutional and regulatory aspects of the management of 
mining and raw materials. In this paper, we focus on the engineering and environmental perspective to identify $\mathrm{CP}$ technologies at the level of aggregate mining companies, e.g., aggregate production.

Comprehensive assessment tools used in the MAREX project are life cycle assessment (LCA) for products and processes as well as material flow analysis (MFA), either to calculate stocks or to calculate flows. LCA comprises the following steps: (a) definition of a goal and the scope (ISO 14040, ISO 14044) $[9,10]$; (b) life cycle inventory analysis, with a definition of the functional unit; (c) life cycle impact assessment (LCIA); and (d) life cycle interpretation. The interpretation phase is intended to deliver results which are consistent with the defined goal and which reach conclusions, explain limitations and provide recommendations. MFA is the study of physical flows into, through and out of a system, and designates a variety of analytical approaches and measurement. Material flows can be analyzed at various scales and using different instruments (e.g., economy-wide material flow accounts at national macro-economic level, individual material flow accounts (MFAcc) at meso level, life cycle inventories (LCI) and substance flow analysis (SFA) at micro level, etc.) [11,12]. LCI compiled in the framework of LCA only quantifies the material flows, whereas LCIA quantifies the related environmental impacts within the defined boundaries. Environmental impacts are classified into impact categories, and include all environmentally-relevant withdrawals from the environment as well as emissions into the environment. The overall scope of the assessment is to determine the environmental optimization potential to achieve a cradle-to-cradle system according to Braungart and McDonough (2002) [13].

The construction of roads and buildings essentially determines the total demand for mineral building materials. Hence, bottom-up MFA at meso level can be used to draw reliable conclusions on the dynamics of regional demand for such materials. Construction master plans form the basis of urban planning activities in Vietnam [14]. The "Construction master plan for Hanoi capital region to 2020, vision to 2050" [8] for the locations Hanoi, Ha TayVinh Phuc, Bac Ninh, Hai Duong, Huen Yen, Hoa Binh and Ha Nam covers a planning area of 13,436 ha. It was approved in 2007 by the decision So 490/QD-TTg. The "Construction master plan for Hoa Binh Province region to 2020" [15], which covers an area of 14,784 ha, was approved in 2012 by decision 1314/QD-UBND. Both documents foresee further major construction activities. On a more general level, such large-scale developments and the subsequent rise in demand for building aggregates makes the need for environmental protection measures and cleaner production technologies ever more urgent.

A key issue in MAREX is Cleaner Production (CP), a philosophy of environmental protection in the production and services sector introduced by the United Nations under its Environment Program (UNEP) [16]. CP is an important method to help develop the circular economy at the level of strategic company positioning. The formulation of Cleaner Production Concepts (CPC) is based on ideas discussed at the 1992 Conference on Environment and Development in Rio de Janeiro. The basis of CPC is the idea of a sustainable, integrated and systematic environmental protection strategy that focuses on processes, products and services. The aim is not only to improve environmental protection but also to raise sustainability by reducing ecological risks through positive economic and social factors while avoiding production factors with a negative environmental impact. CP is an important method for the development of cycle management at the level of strategic company positioning, and includes measures for product-integrated environmental protection (i.e., resource efficiency) and production-integrated environmental protection (i.e., the production process, including health and safety issues). General applications of CP in rock consumption for civil construction are already practiced in Vietnam [17]. The Mineral Law of 2010 constitutes the main regulatory framework for mineral extraction in the country [18]. The regulatory framework for environmental assessment is the obligation to conduct an Environmental Impact Assessment (EIA) and environmental monitoring $[19,20]$. EIA is an approval procedure for environmentally-relevant projects. It requires the conclusion of environmental protection measures, which can be based on environmental modeling, during the approval procedure. $\mathrm{CP}$ measures will encompass all engineering and environmental factors, as the aim here is to promote the integration of product quality, the environment as well as 
occupational health and safety. While resource efficiency potentials can be identified through MFA and LCA, CP considers environmental and social aspects such as environmental protection and the health and safety of miners.

In Vietnam, there is already considerable interest in developing appropriate $\mathrm{CP}$ guidelines for the aggregate mining sector. One significant problem is the small-scale nature of local aggregate mining, which, while respecting established work and environmental protection measures, is rather poor at ensuring resource efficiency. At the international level, resource efficiency is highly promoted in the mining sector. The International Council on Mining and Metals (ICMM) introduced the concept of material stewardship (material responsibility) in its "Maximizing Value: Guidance on Implementing Materials Stewardship in the Minerals and Metals Value Chain" [21], which has been adopted by the OECD and integrated into an economic context [22]. Eco-efficiency is an important factor in choosing and implementing appropriate measures. This concept is defined as the ratio between an economic (monetary) and a physical (ecological) measure, and represents the "economic-ecological efficiency" [23]. In this eco-efficiency relationship, the economic indicator is considered an added value and the ecological indicator an environmental damage [23], whereby the environmental damage corresponds to the sum of all direct and indirect forms of environmental pollution originating from a product or service. Examples of measures to raise eco-efficiency are, for instance, added value per emitted $\mathrm{CO}_{2}$, added value per solid waste or added value per energy consumed [23]. In the mining sector this includes activities to increase the extraction of the raw material from deposits as well as the use of secondary minerals and secondary fractions. In analogy to eco-efficiency, socio-efficiency is the ratio between the added value and social damage, whereby social damage corresponds to the sum of all negative social effects of a product, process or activity. In the context of resource efficiency, eco-efficiency and socio-efficiency can also be applied to the field of mining, and may be used as a framework to foster sustainability in companies.

\subsection{Scope, Motivation and Study Location}

The scope of the present study was to investigate CP potentials in Vietnam's aggregate mining sector through process and life-cycle optimization at the level of the aggregate mining companies while taking into account engineering and environmental factors as well as their interrelations. The demand for construction materials in the building sector, the value chains of the building sector as well as methods to meet demand are all outside the scope of the current paper. Rather, these will be the subject of later publications issuing from a subproject on material flows required to meet future demand for construction materials. The current contribution focuses on the metropolitan area of Hanoi and Hoa Binh Province as its hinterland, where agricultural land and settlements are particularly affected. The location of the capital Hanoi and Hoa Binh Province are shown in Figure 2.

Due to its large limestone and clay deposits, one of the key industries in Hoa Binh Province is the production of building materials. While some of this material is consumed locally, the greatest part is delivered to the City of Hanoi. There are 94 aggregates mining sites in Hoa Binh Province, most located close to the border with Hanoi (Figure 3). 


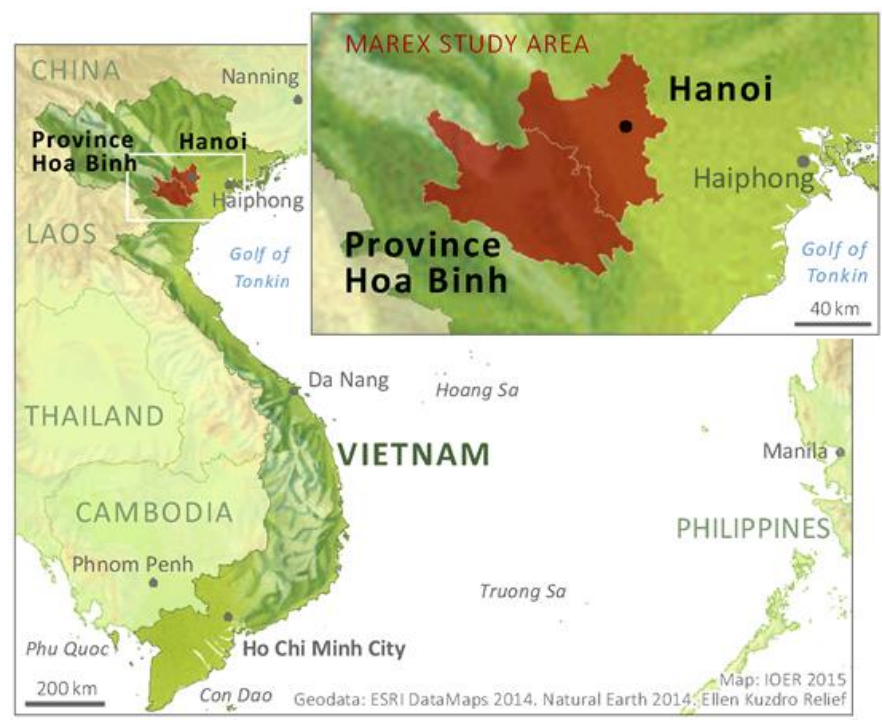

Figure 2. Location of the Vietnamese capital Hanoi and Hoa Binh Province (Source: IOER based on ESRI DataMaps 2014, Natural Earth 2014, Ellen Kuzdro Relief).

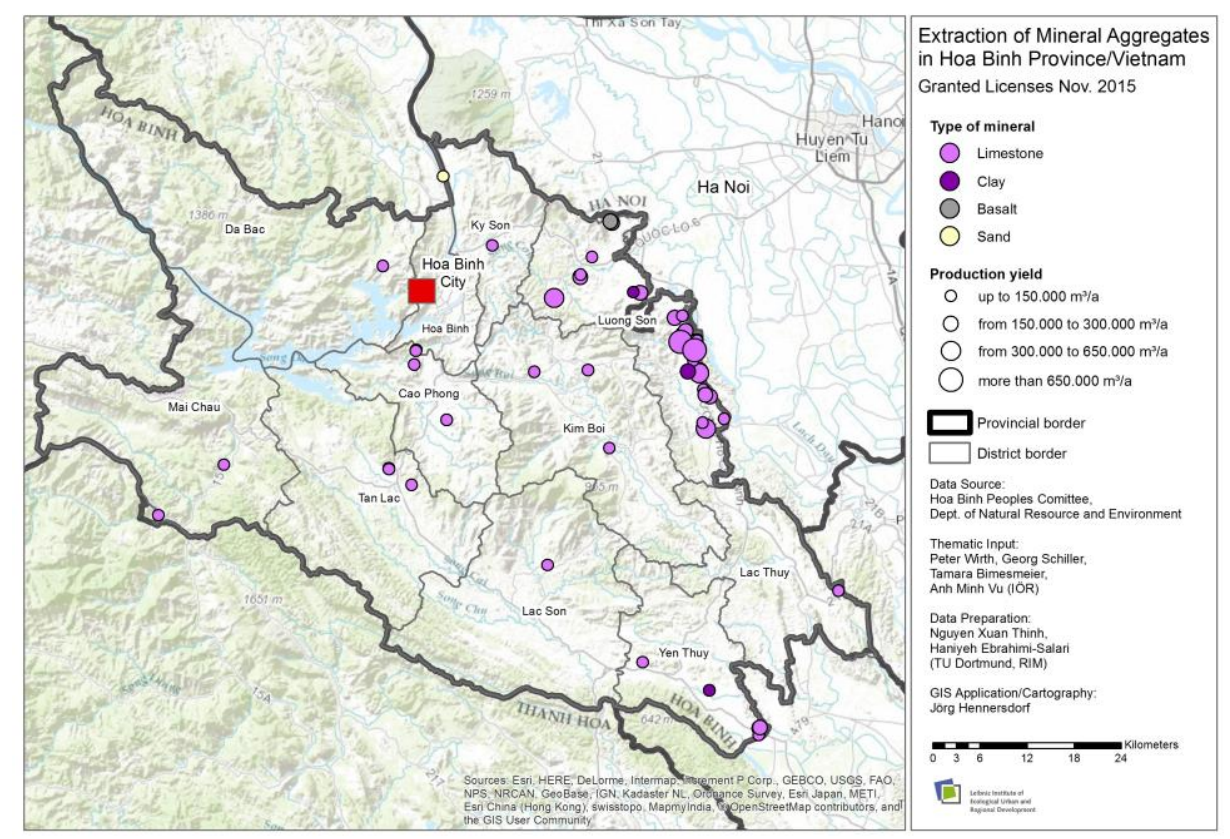

Figure 3. Location of aggregate mining activities in Hoa Binh Province (Source: IOER based on ESRI DataMaps 2014, Natural Earth 2014, Ellen Kuzdro Relief).

Currently, the environmental impacts from aggregate mining are accepted to ensure continued economic growth and urbanization. Licenses for aggregates mining have been more or less freely granted in previous years [14]. While EIA is mandatory for aggregate mines in Vietnam and environmental monitoring is performed, there is little awareness of environmental impacts and the importance of sustainability. Investigation of the current situation in aggregate mining in Hoa Binh Province revealed problems typical of this industry in Vietnam as a whole, which is mainly small-scale in nature.

Beginning with an analysis of the current situation from an engineering perspective, the aim of the study was to investigate in a quantifiable way the potentials for environmental and social improvement as well as the resource efficiency potentials. While the potentials for environmental and 
social improvement could be analyzed by collecting data in the companies, the resource efficiency potential was assessed by LCA at the level of the mining companies. An integrated interpretation of both approaches was used to identify likely sources of CP at the company level.

\section{Materials and Methods}

The study approach was to collect data on aggregate mining companies in Hoa Binh Province by means of a questionnaire and a validating field survey, followed by a technical assessment from an engineering perspective. This led to the formulation of suggestions on how to improve mining operations. The collected data were used to conduct an LCA at the micro level of the mining companies according to ISO 14040:2006 [9,10], including the interpretation of results and conclusions for $\mathrm{CP}$ strategies in the Hoa Binh aggregate mining sector, as well as recommendations on how to raise eco-efficiency and socio-efficiency from an engineering and environmental perspective. The questionnaire (theEnglish-language version of the questionnaire can be found in the Supplementary Materials and results were anonymized to preserve privacy) focused on the following issues:

- Part 1: General Information

- Part 2: Information on the mining companies

- Part 3: Extraction and processing technology as well as material requirements

- Part 4: Resource consumption and environmental aspects

- Part 5: Occupational health and safety.

A special focus of the project was to collect information on the operational status and the type of environmental protection measures already applied, including details of existing $\mathrm{CP}$ implementation and optimization options. In parallel, the LCA was prepared for those surveyed companies with sufficient base data. Figure 4 is a general flowchart of aggregate mining exploration and extraction in Hoa Binh Province, with an indication of LCA system boundaries.

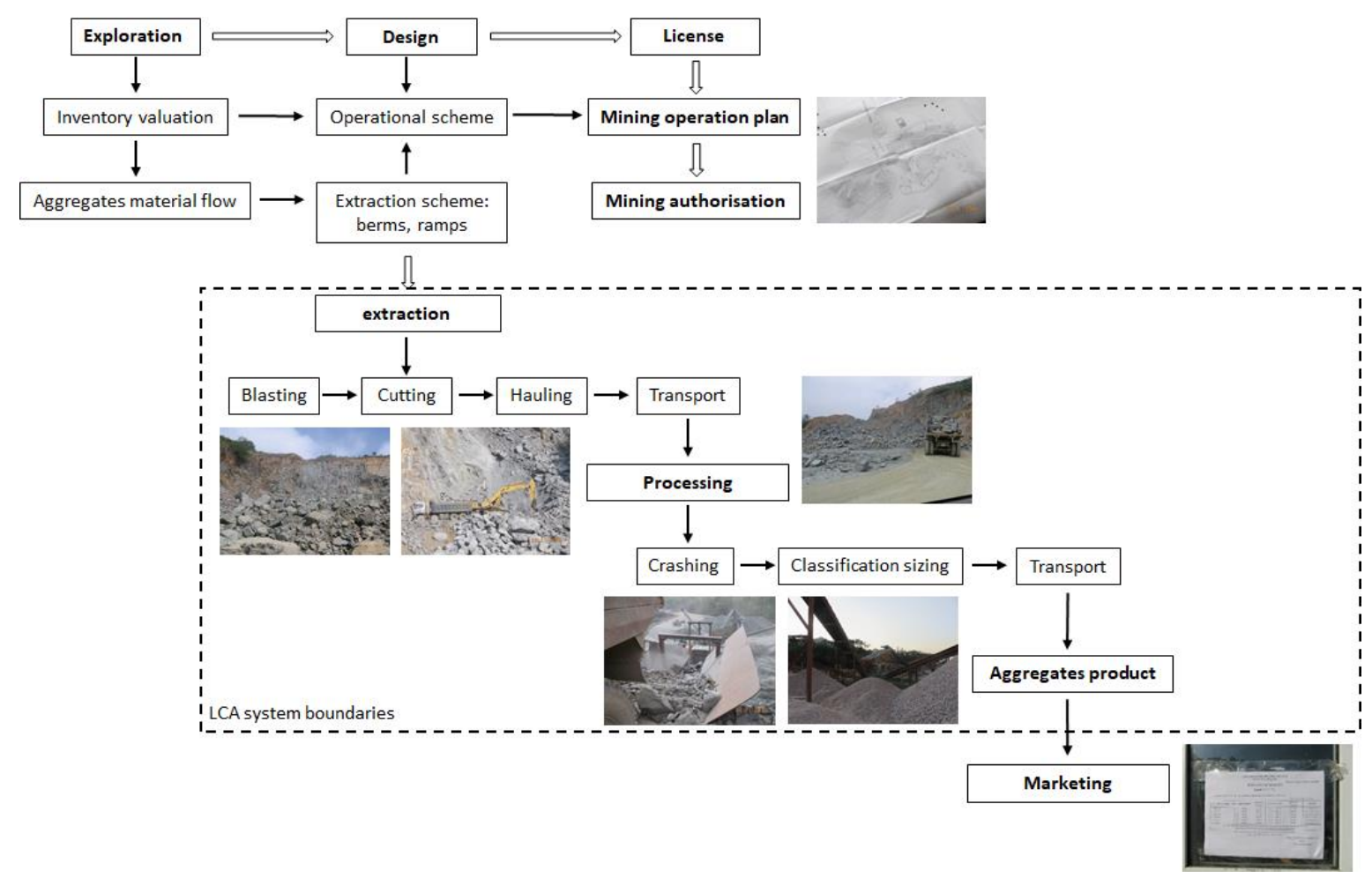

Figure 4. Flowchart of mining operations in Hoa Binh Province with LCA system boundaries. 
The present LCA was prepared using the Global Emissions Model for Integrated Systems (GEMIS), a public domain life-cycle and material flow analysis model and database freely provided by the International Institute for Sustainability Analysis and Strategy (IINAS) [24]. The program provides quantifiable LCIA parameters under consideration of midpoint impact categories. Similar to other LCA software tools, it summarizes the impact for several sub-processes. According to Bare et al. (2000) [25], midpoints are considered to be links in the cause-effect chain (environmental mechanism) of an impact category, at which characterization factors or indicators can be derived to reflect the relative importance of emissions or extractions. Impact categories are classes representing environmental issues of concern to which LCIA results may be assigned [9,10]. GEMIS consists of an analysis model to determine energy and material flows (including transport), as well as a database.

The analysis model calculates lifecycles for processes and scenarios, i.e., it considers all processes from resource extraction (primary energy and, raw materials) to final energy or material use, and also includes auxiliary energy and material uses as well as materials for constructing energy, material and transport systems. The impact categories in the present LCA were selected due to their representativeness for aggregate mining and the availability of respective data in the GEMIS database. Results were validated using the eco-bau LCAs of the Swiss Society of Sustainability in Public Construction [26], an association jointly set up by federal and local construction authorities in Switzerland to promote ecological and healthy building. The system boundaries in the present LCA encompass the activities of extraction and processing as well as the internal traffic at the processing site undertaken to obtain the product (limestone and basalt aggregates). Further processing, transport to the construction site, use as building material and recycling are not subject of investigation.

The classification of the impact categories from A (highest priority) to D (lowest priority) serves to assess indicator results. The impact categories were subdivided into ecological hazards and distance-to-target (distance to the desired environmental condition). Ecological hazards can be used to assess an impact category regarding the extent of damage to human health, the structure and function of ecosystems as well as natural resources. In terms of distance-to-target, an impact category is ranked higher when the current environmental status in this impact category deviates negatively from the desired state. Hence, it refers to a higher probability of ecological damage. The considered impact categories are:

Resource consumption, in the present assessment, refers to abiotic resources, subdivided into renewable (water), non-renewable (natural gas, ores, minerals) and others (secondary raw materials, iron scrap).

Cumulative Energy Demand (CED) is a measure of the total expenditure of energy resources to provide a product. CED is subdivided into renewable (hydropower) and non-renewable (coal, petroleum, natural gas) primary energy sources.

Global warming Potential (GWP) is a relative measure of how much heat a greenhouse gas traps in the atmosphere. As the temperature of the lower atmospheric layer increases, this leads to changes in the composition and geographic distribution of ecosystems as well as having a negative impact on biodiversity.

Eutrophication describes the phenomenon of excessive plant growth in water bodies due to high concentrations of the nutrients phosphorus and nitrogen. The excess plant biomass can only be used to a limited extent by primary consumers and is decomposed by microbes. The over-fertilization can decouple aquatic material cycles.

The acidification of soils and water has various detrimental effects on plants, animals and ecosystems (e.g., root damage and increased erosion of important nutrients). The observed secondary effects include long-term changes in species composition and the genetic variability of remaining species, decreased resistance to other anthropogenic and natural stresses, and finally system collapse.

Photochemical generation of oxidants-TOPP (Tropospheric Ozone Precursor Potential, that is summer smog): Increased ozone levels can damage vegetation by oxidation, which forms free radicals 
and harms cell functions. This is expressed in premature aging, reduced vitality and greater sensitivity of plants to stress factors. Summer smog affects biodiversity as well as causing harvest shortfalls.

Tables 1 and 2 provide a summary of the adopted methodology, the impact categories and the input and output parameters. The datasets were processed and adapted to each site using the GEMIS (Global Emission Model of Integrated Systems) database. The limestone quarry Ostrau in Saxony (Germany) serves as a benchmark due to its optimized, resource-efficient operation. This quarry fulfills the benchmark criteria for a resource-efficient operation given in Korak (1978) [27] and Braun et al. (2017) [28]. Ostrau has a limestone deposit of depth $20 \mathrm{~m}$ and an average extraction volume of 300,000 $\mathrm{m}^{3} /$ year. $(\approx 500,000$ tons/year). Depending on the type of mining equipment, Braun et al. (2017) specify a resource-efficient operation at 200,000 tons/year. for pit depths of $20 \mathrm{~m}$, and 2.3 million tons at pit depths of $140 \mathrm{~m}$. Only a few of Vietnam's aggregate mines achieve such volumes, and therefore cannot be considered resource-efficient mining operations. Ostrau represents a state-of-the-art opencast mining facility with slopes, berms and ramps to guarantee continuous mineral extraction, which is the Best Practice form of aggregate mining according to Australia's Department of Economic Development, Jobs, Transport and Resources (2010) [29]; Agioutantis et al. (2011) [30], Agioutantis and Athousaki (2011a) [31], and Agioutantis and Athousaki (2011b) [32].

Table 1. Ranking of impact categories according to the German National Environmental Agency.

\begin{tabular}{ccc}
\hline Characteristics & Ecological Hazards & Distance-to-Target \\
\hline Eutrophication & $\mathrm{B}$ & $\mathrm{C}$ \\
TOPP & $\mathrm{D}$ & $\mathrm{B}$ \\
Resource consumption & $\mathrm{C}$ & $\mathrm{B}$ \\
Global warming & $\mathrm{A}$ & $\mathrm{A}$ \\
Acidification & $\mathrm{B}$ & $\mathrm{B}$ \\
\hline
\end{tabular}

Table 2. Overview of the impact categories for Hoa Binh.

\begin{tabular}{|c|c|c|}
\hline Impact Category & Parameter & Unit \\
\hline \multicolumn{3}{|l|}{ Input (Input-related categories) } \\
\hline $\begin{array}{l}\text { Resource consumption (Abiotic } \\
\text { resources) }\end{array}$ & $\begin{array}{l}\text { Iron waste, ores, natural gas, } \\
\text { water, secondary raw materials }\end{array}$ & $\mathrm{kg}$ \\
\hline $\begin{array}{l}\text { Energy consumption-CED } \\
\text { (cumulative energy demand) }\end{array}$ & $\begin{array}{l}\text { non-renewable resources (oil, coal, } \\
\text { natural gas), renewable resources } \\
\text { (water power) }\end{array}$ & $\mathrm{kWh}$ \\
\hline \multicolumn{3}{|l|}{ Output (output related categories) } \\
\hline $\begin{array}{l}\text { Global warming (global warming } \\
\text { potential, GWP) }\end{array}$ & $\mathrm{CO}_{2}, \mathrm{CH}_{4}, \mathrm{~N}_{2} \mathrm{O}$ & kg CO 2 -equivalent \\
\hline Eutrophication & $\mathrm{P}, \mathrm{N}, \mathrm{NO}_{\mathrm{X}}, \mathrm{NH}_{3}$ & $\mathrm{~kg} \mathrm{PO}_{4}{ }^{3-}$-equivalent \\
\hline Acidification & $\mathrm{SO}_{2}, \mathrm{NO}_{X}, \mathrm{NH}_{3}, \mathrm{HCl}, \mathrm{HF}, \mathrm{H}_{2} \mathrm{~S}$ & $\mathrm{~kg} \mathrm{SO}_{2}$-equivalent \\
\hline $\begin{array}{l}\text { Tropospheric ozone precursor } \\
\text { potential TOPP (photochemical } \\
\text { oxidation) }\end{array}$ & $\mathrm{CO}, \mathrm{CH}_{4}, \mathrm{NMVOC}, \mathrm{NO}_{X}$ & $\mathrm{~kg}$ ethene-equivalent \\
\hline
\end{tabular}

The scope of the LCA investigation was the comparative investigation of the impacts on the environment of 11 representative aggregate mines in Hoa Binh Province and the identification of their resource efficiency potential to enhance the sustainability of mining operations (limestone and basalt quarries). The case study comprises the value chain within the system boundaries illustrated in Figure 4 from initial exploration up to the marketable aggregate. Information about the consumption of energy (hydropower, coal, and diesel), water and explosives as well as the annual extraction of limestone or basalt is obtained from a questionnaire and a validating field survey (see Table 4 . By implementing this input data into GEMIS processes, it was possible to quantify, categorize and then evaluate the 
related parameters to draw conclusions about the environmental impacts of the mining activities. A detailed illustration of the relationship between the generated products, input data, GEMIS processes, environmental parameters and impact categories can be found in the Supplmentary Materials.

The LCA is based on the assumption that electrical energy is provided entirely from hydropower and coal, based on the energy mix from the Pha Lai coal-fired power plant and the Hoa Binh water power plant [33]. The consumption of diesel is limited to trucks operating on the mining sites. Regarding environmental pollution caused by explosives, the only such explosive in use was ANFO (ammonium nitrate/fuel oil). The water supply was considered without further environmental effects, i.e., without upstream value chains. The functional unit is defined as 1 ton of mined material (excluding overburden). The temporal system boundary is the annual production in 2016.

\section{Results}

\subsection{Selected Survey Results}

Of the 94 approved aggregates mining sites in Hoa Binh Province, 51 are in operation, 8 have ceased operation, and 35 are currently applying for a license. Most of the mines provide limestone with only a few basalt and clay mines. Aggregates are mined exclusively in quarries. The total volume extracted by the surveyed companies in 2016 was 1.96 million tons. Regarding the business structure of the various mining companies, $44.4 \%$ are limited companies, $29.6 \%$ are joint stock company with the others showing a range of organizational forms.

The mean excavation area is 7.3 ha. Almost $50 \%$ of excavation sites are smaller than 5 ha with $80 \%$ smaller than 15 ha (Table 3). The licensed extraction quantity of the 27 companies which responded to the questionnaire is shown in Figure 5. It ranges between 5 and 30,000,000 million $\mathrm{m}^{3} /$ year. Many companies are classified as micro-enterprises as the annual output is $\leq 40,000 \mathrm{~m}^{3}$.

Table 3. Summary of excavation areas of the aggregate mining companies.

\begin{tabular}{ccc}
\hline Excavation Area & Number of Companies & $\mathbf{\%}$ \\
\hline$<5$ ha & 13 & 48.1 \\
$5-10$ ha & 6 & 22.2 \\
$10-15$ ha & 3 & 11.1 \\
$15-20$ ha & 4 & 14.8 \\
$>20$ ha & 1 & 3.7 \\
\hline
\end{tabular}

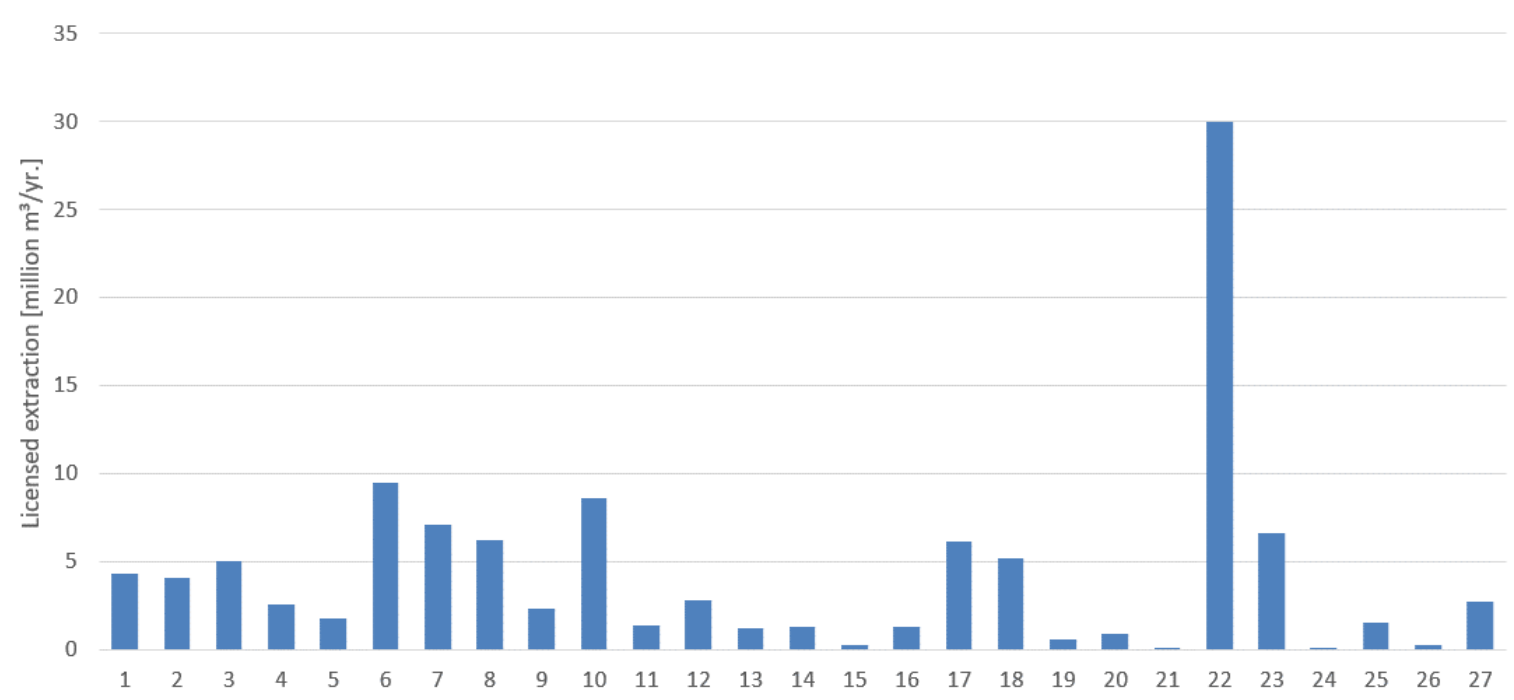

Figure 5. Licensed extraction quantity of the companies which responded to the survey. 
Figure 6 shows the real mining capacity of the companies which responded to the survey. Figures range 25,000-360,000 tons/year, indicating that the majority of the companies are too small to achieve resource-efficient mining. The information obtained in the survey was used as input data for the LCA.

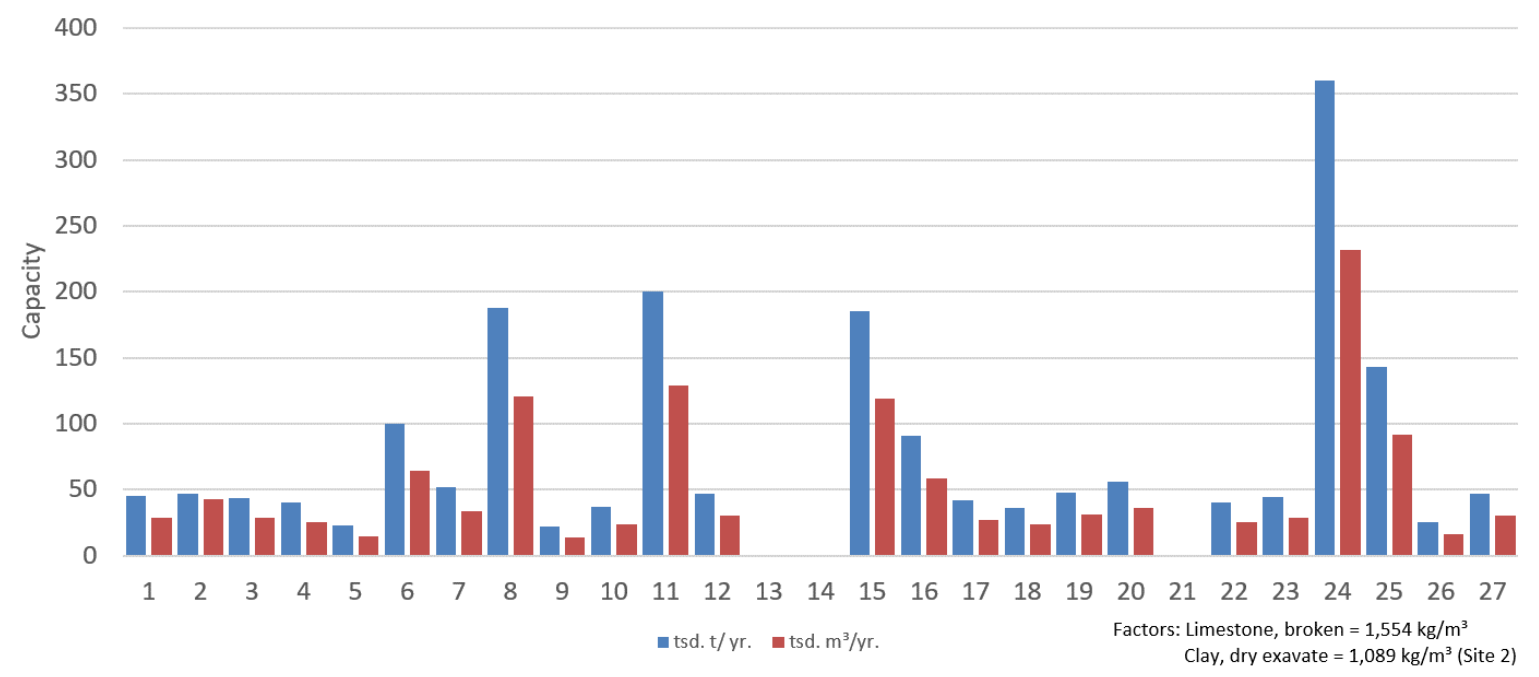

Figure 6. Real mining capacity of the companies which responded to the survey.

Overall, $65.4 \%$ of the companies have a license to mine for a period of more than 30 years. Of the 15 companies that reported profits in 2015, four suffered losses (only one company provided a figure for the loss). The average profit for companies which provided information on this question is $1.4 \%$ of total turnover. None of the companies received government grants. The average annual environmental tax (17 replies) is approximately $266 \mathrm{mVND}(\approx \mathrm{US} \$ 11,700)$. Values range from approximately 21.9 $\mathrm{mVND}(\approx 962 \mathrm{US} \$)$ to approximately $852 \mathrm{mVND}(\approx \mathrm{US} \$ 37,500)$. Of the 27 companies, 15 named their main sales market as Ha Noi, 20 as Hoa Binh Province and four named other markets. The average sales price when selling directly in the quarry is $80,000 \mathrm{VND} / \mathrm{t}(\approx \mathrm{US} \$ 3.52)$, with prices ranging from $45,000 \mathrm{VND} / \mathrm{t}(\approx \mathrm{US} \$ 1.98)$ to $113,000 \mathrm{VND} / \mathrm{t}(\approx \mathrm{US} \$ 4.97)$. Two companies gave the same price for on-site delivery at $126,000 \mathrm{VND} / \mathrm{t}(\approx \mathrm{US} \$ 5.54)$. The average transport price for the six companies which provided information is approximately $4700 \mathrm{VND} / \mathrm{t}(\approx \mathrm{US} \$ 0.21)$, with a range of values from free delivery up to $\approx 8000 \mathrm{VND} / \mathrm{t}(\approx \mathrm{US} \$ 0.35)$.

Figure 7 shows the various measures to reduce environmental impacts named by $74 \%$ of surveyed companies. No other measures for the reduction of impacts were reported. Fourteen companies provided information on waste generation. The types of waste encompass wastewater and solid waste, dust and rock wastes, as well as industrial waste (multiple entries possible).

The information provided by the questionnaires implies that: (a) there is a general awareness of environmental and social impacts; and (b) safeguards are implemented, in particular where environmental impacts are small and/or directly affect employees.

The following measures to reduce energy consumption were reported by the surveyed companies (14 responses): The efficient use of raw materials, energy- and water-saving, the use of modern equipment, management of production output, regular maintenance of machines, production at times of the day with lower priced electricity, energy savings with respect to machines and equipment, the efficient use of electricity and water, safe vehicles for transport, power-saving by switching off machines/devices after use. Eight companies named further suitable measures to reduce environmental impacts such as waste reduction at source, reducing the waste of natural resources and the orderly storage of equipment and material. 


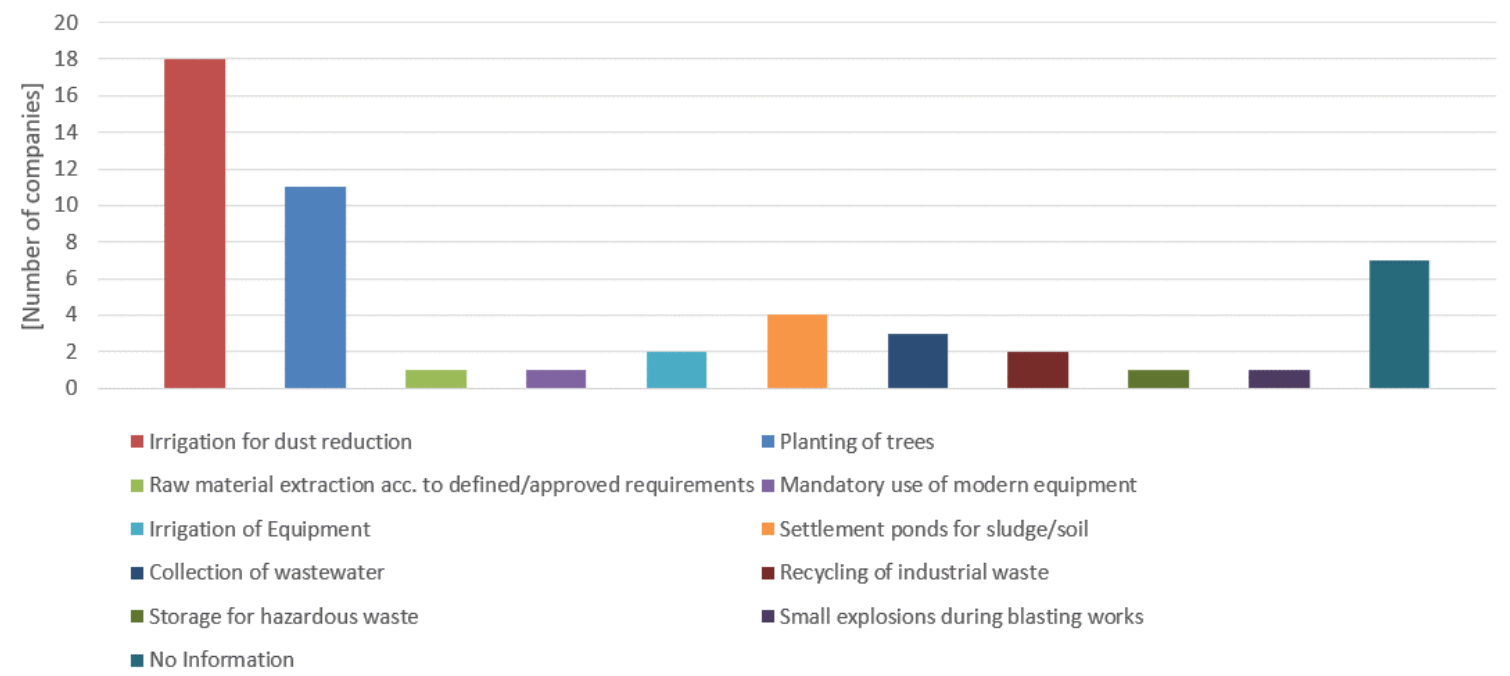

Figure 7. Measures named by the surveyed companies to reduce environmental impacts.

\subsection{Engineering Perspective: Identified Gaps}

From an engineering perspective, three types of gaps were identified as having an impact on the companies' operational performance, their resource efficiency potential as well as environmental and social impacts: (a) operational gaps; (b) institutional gaps; and (c) organizational gaps.

Identified operational gaps: Almost all of the investigated opencast mines show non-compliance with Best Practice technologies in open cast mining. Instead of standard exploration and pre-processing techniques such as the construction of slopes, berms and ramps, dangerous and haphazard exploitation techniques are applied with no continuous mineral extraction. Manual extraction by climbing on to the rock face to blast an area of rock is extremely dangerous for the workers, who transport the drilling equipment and explosives uphill without any protective equipment (see Figure 8). Technical solutions cannot be applied due to the missing slopes, berms and ramps. This kind of uncontrolled extraction can be partly attributed to the small size of the licensed operation areas.
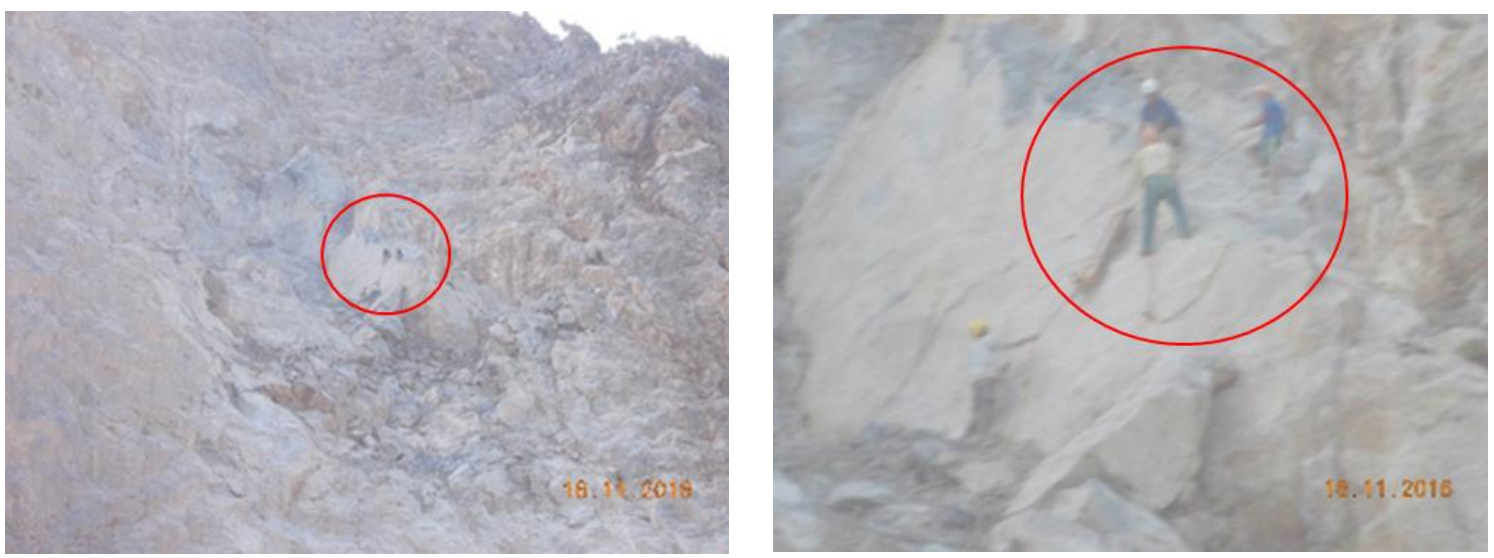

Figure 8. Visual impression of current exploration techniques (right picture zoomed in).

While some companies could present well executed design documents approved by the responsible and competent authorities, there are large discrepancies between the approved design of mining operations and the applied mining techniques (see Figure 9). While the approved design of the mining operation represents Best Practice by taking account of all necessary operational structures, in reality, the mines are constructed with much simpler structures. This also implies insufficient operational supervision by the responsible authority. 

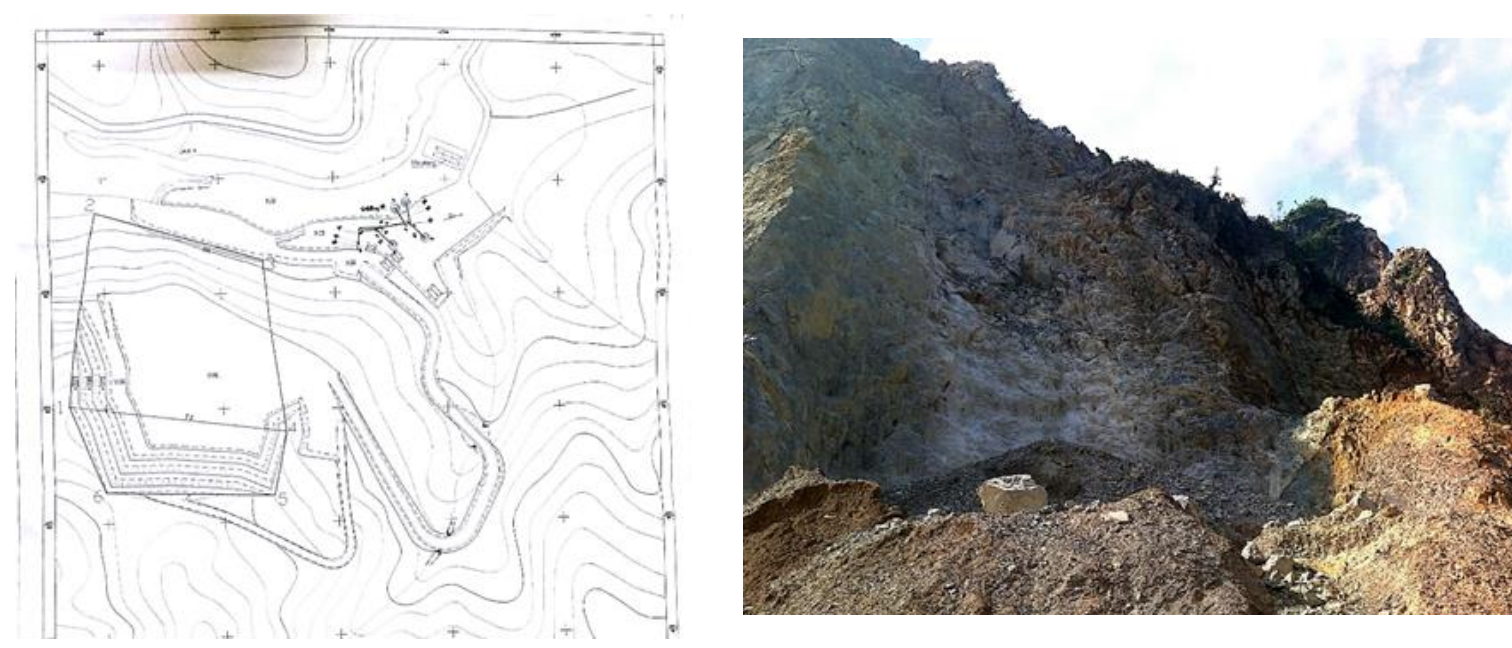

Figure 9. Discrepancy between approved and applied mining techniques: Although the mine is designated for standard "group-extraction method", in reality hill extraction is performed.

Identified institutional gaps: According to Best Practice, well-designed exploratory and pre-processing technology is essential to ensure the continuous mining of aggregate deposits. Under current licensing and financing practices, some companies are unable to implement state-of-the-art preparation and extraction technology since licenses are awarded for overly small extraction volumes and mine surfaces (due to boundary conflicts with neighbors). This produces a resource efficiency potential from the mining of aggregate deposits lying in boundary areas and the optimized use of the machinery (savings in fuel consumption and exhaust gases). The resource efficiency potential can be quantified through the LCA.

Identified organizational gaps: The number of separate mining sites would be reduced if the aggregate was extracted at bigger sites, helping to boost resource productivity considerably. Small-scale mining activities lead to high extraction losses since maximum extraction is prevented by the narrowly designated mining strips, which block a large share of the resources. Therefore, there are currently strict limits to the application of resource-efficient technologies, which can only be implemented in certain process steps such as drilling blasting, crushing and sieving as well as hauling and transport.

The small-scale nature of mining operations ( $50 \%$ of mines are less than $5 \mathrm{ha}$ ) means that the annual extraction volume for each mine is less than $50,000 \mathrm{~m}^{3} /$ year. In comparison, the average German mine produces $300,000 \mathrm{~m}^{3}$ /year. This is insufficient to generate revenue for investment in technology and equipment. Further, the approved quantities of aggregate mean that the quarries have a relatively short active lifetime. The mining companies are unable to invest to improve the existing situation due to the low revenues from such non-efficient operations. In addition, they find it difficult to obtain loans for investment due to the low productivity.

\subsection{Implemented CP Measures}

Due to the low revenues from their non-efficient operations, the main focus of the mining companies is currently on social and environmental protection measures, which are implemented to the extent required by law.

The aggregate companies practice occupational health and safety (OHS) measures, usually with an internal OHS management system for: (a) machines and equipment; and (b) operating activities. The measures include protection against noise and vibration as well as dust reduction. In particular, standard dust protection methods are applied such as sprinkler and irrigation systems, the covering or shielding of the dust source and the use of modern equipment. Regular health checks are also carried out. Measures for dust control are carried out in $89 \%$ of the companies. All companies provided information on the personal protective equipment (PPE) of employees. The following measures are 
named: protective helmets $(92.5 \%)$, protective shoes $(92.5 \%)$, protective gloves $(92.5 \%)$, dust masks $(92.5 \%)$, protective goggles $(70.4 \%)$ and protective clothing $(96.2 \%)$. Because the majority of the companies are too small for long-term operations, a budget for environmental protection measures is only allocated if: (a) required by law; or (b) the measures are complementary with OHS measures, e.g., a green belt for dust protection.

\subsection{LCA Variant Assessment}

\subsubsection{Input Data for the LCA}

The validated information obtained by the survey was used to prepare the LCA for 11 aggregate mining companies. As the results from the survey indicated high resource efficiency potential, two LCA variants were considered: (a) the existing situation; and (b) the option of merging small companies into a larger entity to improve resource productivity. After merging, the new companies would be sufficiently large to adopt Best Practice methods. Such merging was foreseen for companies that are directly adjacent. The analysis posited the formation of one large mine to replace two small mines. The higher resource efficiency results from the mining of aggregate deposits at the boundary between two mines and an optimized use of the machinery to reduce fuel consumption and exhaust gases.

Table 4 shows the LCA input data of the quarries in Hoa Binh. The current state of each site was considered, with the German mine Ostrau serving as a benchmark (site 1). It should be noted that the numbering of sites in Table 4 is not identical to that of the questionnaire, as only selected locations with sufficient base data were used to conduct the LCA. The life cycle inventory of the quarries is based on the current situation that Sites 2-12 have a machinery utilization rate of approximately $50 \%$ with the benchmark Ostrau at $90 \%$.

Table 4. LCA input data for the quarries in Hoa Binh.

\begin{tabular}{rccccccc}
\hline & \multicolumn{3}{c}{ Energy $\mathbf{( k W h / t )}$} & Water $\mathbf{( k g / t )}$ & $\begin{array}{c}\text { Explosive } \\
(\mathbf{k g} / \mathbf{t})\end{array}$ & $\begin{array}{c}\text { Extraction } \\
(\mathbf{t} / \text { Year) }\end{array}$ & Rock $^{\mathbf{1}}$ \\
\cline { 2 - 4 } & Hydropower Coal & Diesel & & & & \\
\hline Site 1 & 2.13 & 1.87 & 8.99 & 8.35 & 0.23 & 547,980 & $\mathrm{~L}$ \\
Site 2 & 3.91 & 3.45 & 7.37 & 1.33 & 0.20 & 366,765 & $\mathrm{~B}$ \\
Site 3 & 2.21 & 1.94 & 6.6 & 0.77 & 0.20 & 361,490 & $\mathrm{~B}$ \\
Site 4 & 7.99 & 7.04 & 8.53 & 8.37 & 0.37 & 86,000 & $\mathrm{~L}$ \\
Site 5 & 16 & 14.11 & 24.49 & 4.93 & 0.19 & 73,069 & $\mathrm{~L}$ \\
Site 6 & 13.58 & 11.97 & 8.47 & 24.84 & 0.38 & 56,363 & $\mathrm{~L}$ \\
Site 7 & 20.7 & 18.25 & 7.74 & 23.09 & 0.11 & 69,308 & $\mathrm{~L}$ \\
Site 8 & 14.77 & 13.02 & 6.98 & 26.33 & 0.10 & 68,376 & $\mathrm{~L}$ \\
Site 9 & 1.3 & 1.15 & 7.68 & 11.58 & 0.10 & 155,400 & $\mathrm{~L}$ \\
Site 10 & 3.16 & 2.78 & 14.76 & 2.97 & 0.03 & 80,808 & $\mathrm{~L}$ \\
Site 11 & 1.37 & 1.21 & 3.99 & 3.65 & 0.1 & 164,374 & $\mathrm{~L}$ \\
Site 12 & 10.89 & 9.6 & 5.43 & 10.93 & 0.2 & 131,709 & $\mathrm{~L}$ \\
\hline
\end{tabular}

${ }^{1} \mathrm{~B}=$ Basalt, $\mathrm{L}=$ Limestone.

\subsubsection{LCA Results for the Current Situation}

Figure 10 shows the LCA for the current state regarding water consumption. Depending on the type of processing, water consumption ranges from 8 to $60 \mathrm{~L} /$ ton. The results for the consumption of other raw materials per functional unit (FU) are given in Figure 11. Here, the raw materials are secondary raw materials, iron, natural gas and ores which are consumed during the process of aggregate production. The GEMIS base data does not distinguish between the type of secondary raw materials, but refers to all mineral material in the material cycle which could be recycled. The results for Sites 5-8 stand out in view of their low resource productivity, meaning that more raw materials are consumed during the production process than at the other sites (Figure 11). 


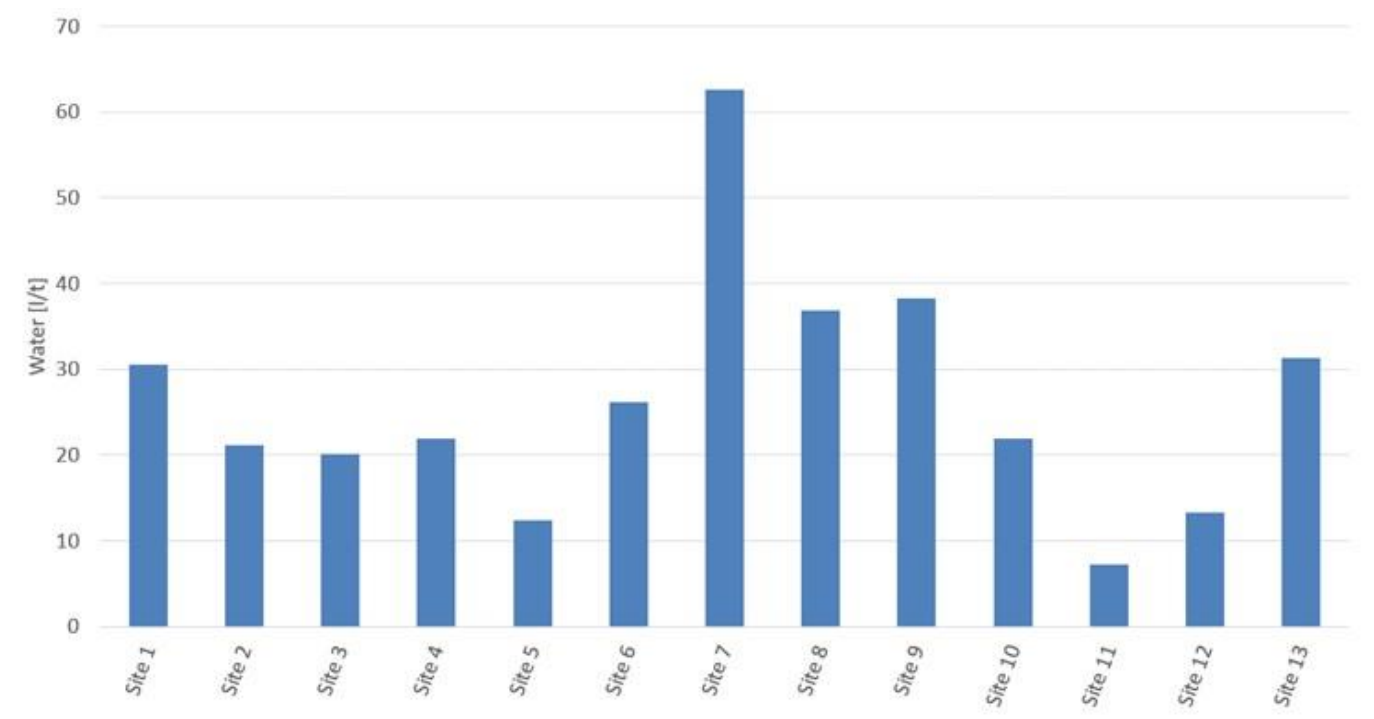

Figure 10. LCA for the current state regarding water consumption.

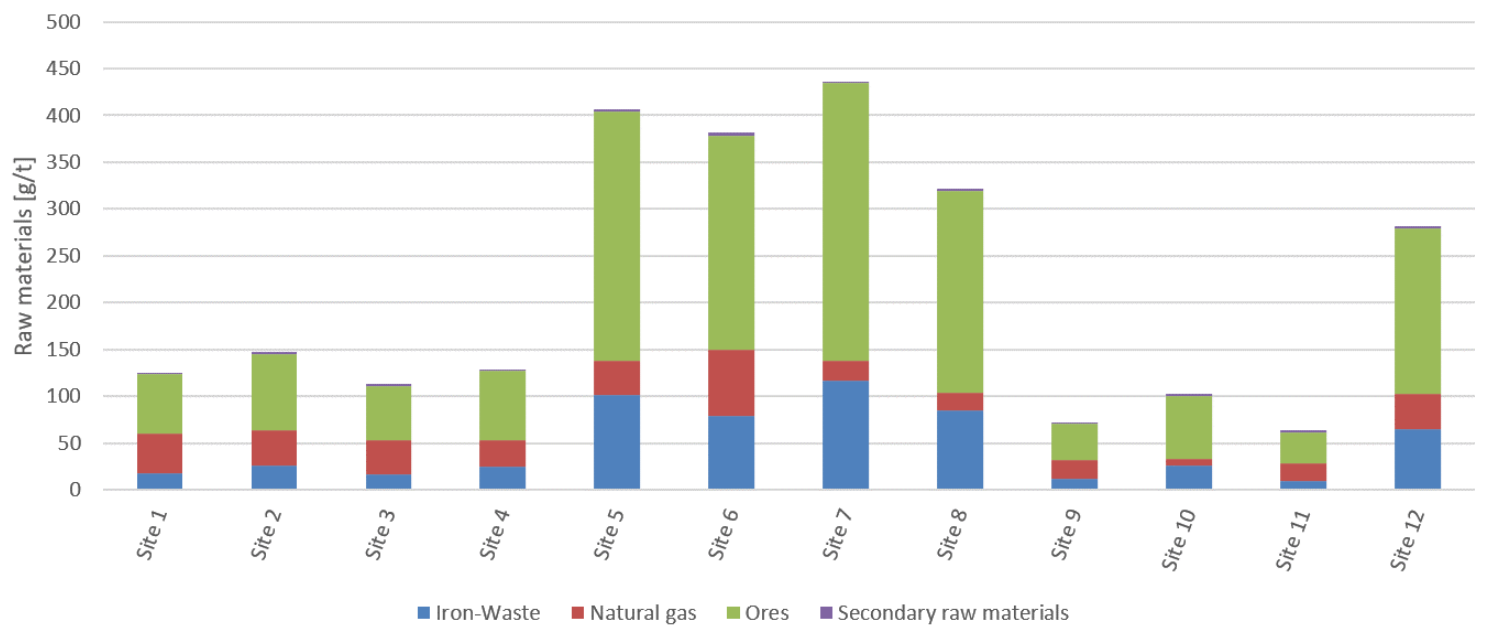

Figure 11. LCA for the current state regarding raw material consumption, i.e., secondary raw materials, iron, natural gas and ores.

The mineral extraction at these sites ranges from 56,000 to 86,000 tons/year. In addition, the energy consumption at these locations is above average. Since the LCA also includes the upstream chains in the environmental assessment, the calculation takes account of raw materials required for energy generation. This also applies to Site 12, although it is significantly more productive at 130,000 tons/year than Sites 5-8. However, the relative energy consumption for extraction is significantly higher than for companies with comparable extraction volumes.

Naturally, these trends are also reflected in the graphs for cumulative energy consumption (Figure 12) and the global warming potential (Figure 13). Companies which consume a higher proportion of non-renewable energy sources (oil, coal, natural gas and water power) during the production process show a greater global warming potential, as indicated in Figure 13. 


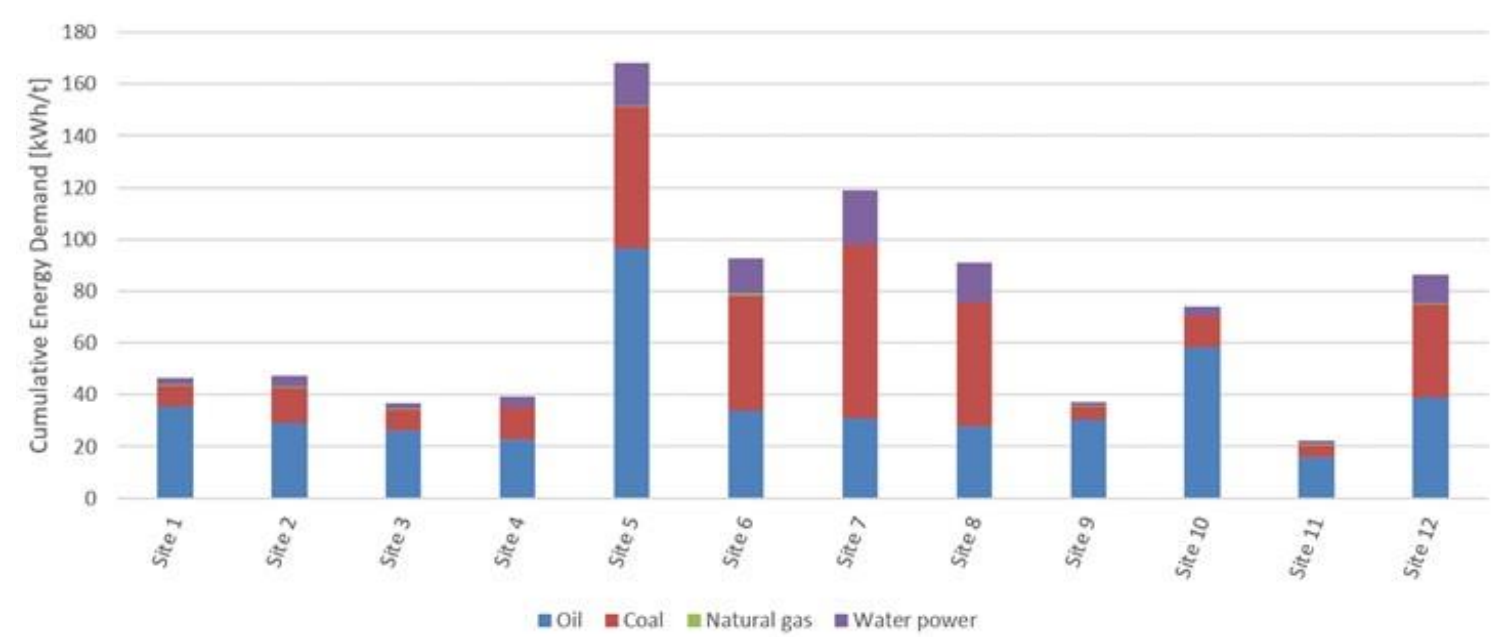

Figure 12. LCA for the current state of cumulative energy demand.

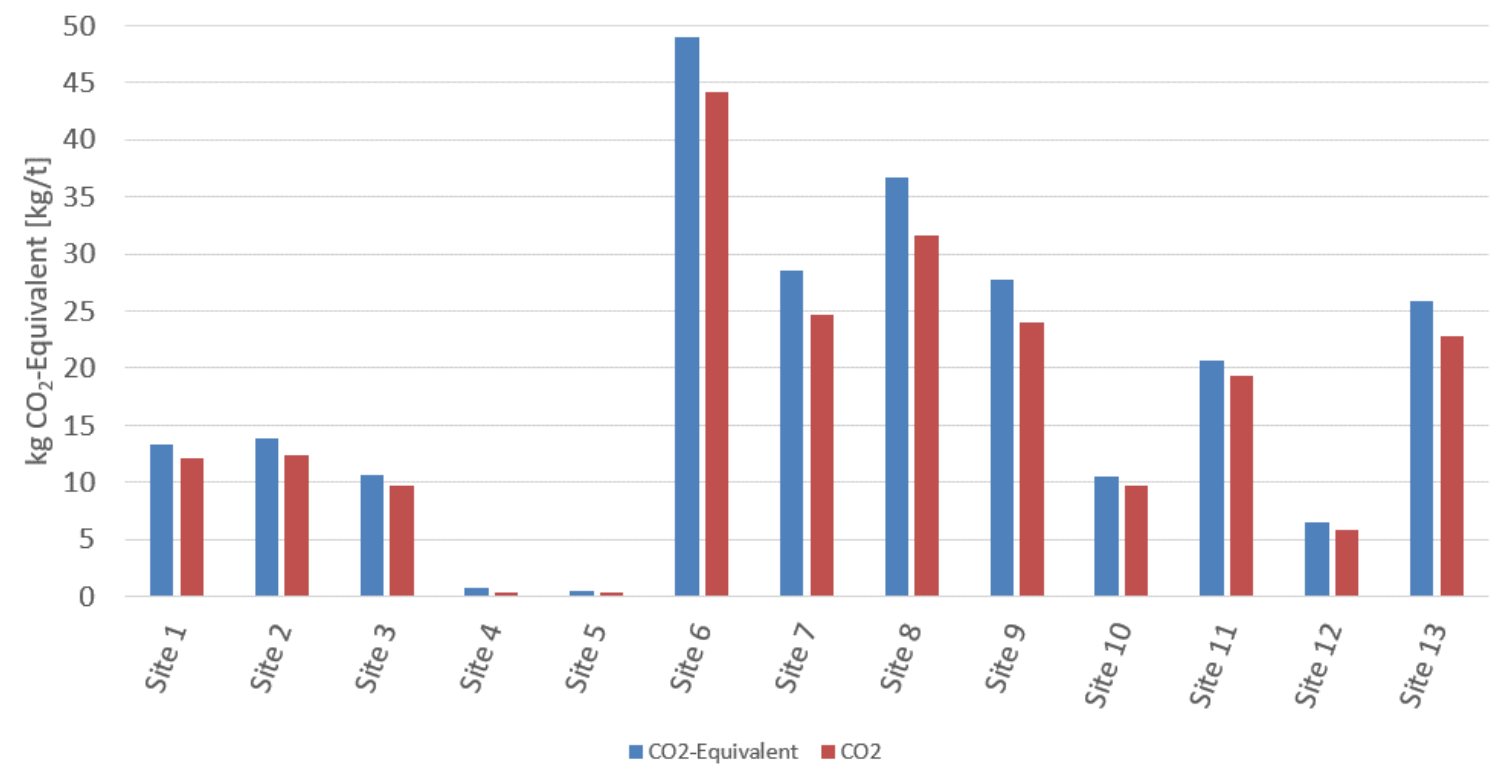

Figure 13. LCA for the current state of the global warming potential.

The LCA results with regard to the production of aggregates is determined by the energy demand for electricity and diesel for power units and the vehicle fleet. Regarding electricity, the damage potential is primarily determined by the value pre-chain, i.e., largely coal burning. This is particularly obvious at Site 5, where the CED is more than $100 \mathrm{kWh}$ above the reference value of Ostrau while running at only $50 \%$ of maximum capacity. Clearly, energy consumption has a dominant influence on almost all impact categories, especially those linked to the value pre-chain (exploration, transformation, etc.). Figures 12-14 show that Site 5 has the maximum values in each category, and therefore we can expect the greatest environmental impacts occurring here. However, an increased environmental risk can be detected at almost all sites. Figure 14 shows the LCA for the current state regarding the environmental impact categories eutrophication, acidification potential and TOPP. 


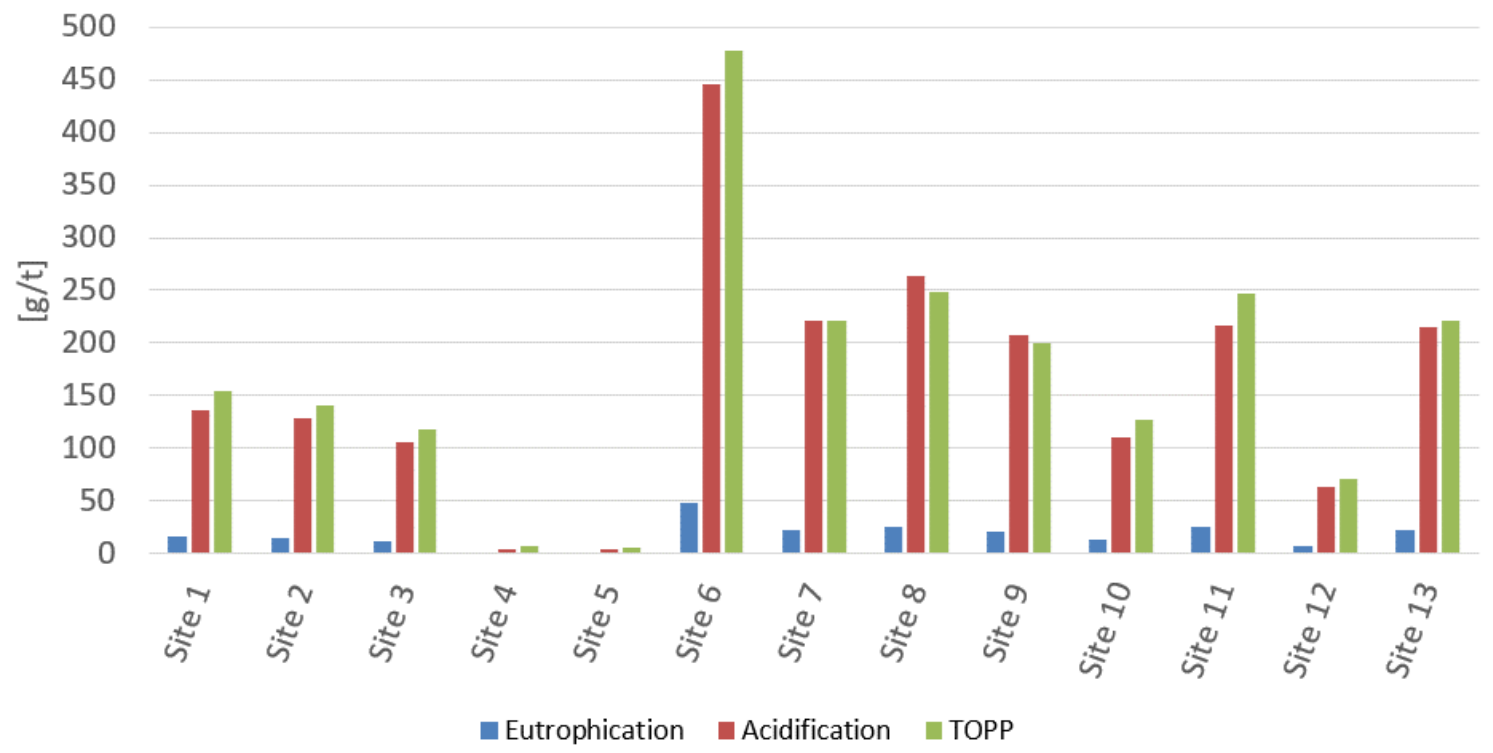

Figure 14. LCA for the current state regarding the environmental impact categories: eutrophication, acidification potential and tropospheric ozone precursor potential (TOPP).

At first glance, some sites (e.g., Sites 2 and 3) seem to have similar values to the reference site. However, it should be remembered that these opencast mines are running at only $50 \%$ capacity, whereas Ostrau provides $90 \%$ capacity utilization (the capacity utilization value is derived from field observations that most of the companies are over-mechanized, and machines are only sporadically in operation). The only site which is comparable to Ostrau in all categories of activity is Site 11. To achieve a more sustainable and environmentally-friendly production of aggregate, work processes must be coordinated to increase the operating times of equipment. Furthermore, mining work at adjacent sites could be combined to ensure a higher rate of operation of machines and equipment.

\subsubsection{LCA Prognosis of a Potential Future Situation}

The effects of merging the following quarries were assessed:

- $\quad$ Sites 1 and 2;

- $\quad$ Sites 6 and 11;

- $\quad$ Sites 7 and 8 ; and

- $\quad$ Sites 5, 10 and 12 .

Based on the current operating capacities derived from field observations, it was assumed that the merging of adjacent sites could improve capacity utilization at each individual site by at least $50 \%$, with significant energy and resources savings as well as reductions in emissions as some machines and vehicles enjoy higher utilization rates while others are discarded. Furthermore, it is assumed that water consumption will not change as the utilization of the equipment is increased; as the water is recycled, merging merely increases the throughput volume. The quantity of explosives also remains unchanged, since it can be assumed that the type of extraction does not change. The resource savings are shown in Figure 15 without a breakdown of specific minerals as this depends on the material to be mined. Figures 16 and 17 give the LCA results for the merging options regarding global warming potential, eutrophication, acidification potential and TOPP. Savings in terms of the emission indicator (IE) were calculated according to following formula:

$$
\text { Emission }=(\text { IEmax }- \text { IEmin }) / \text { IE max }
$$


where IEmax is the emission value during the individual analysis (e.g., Site 1, Site 2, etc.); and IEmin is the emission value after merging (e.g., merged Sites $1+2$ ).

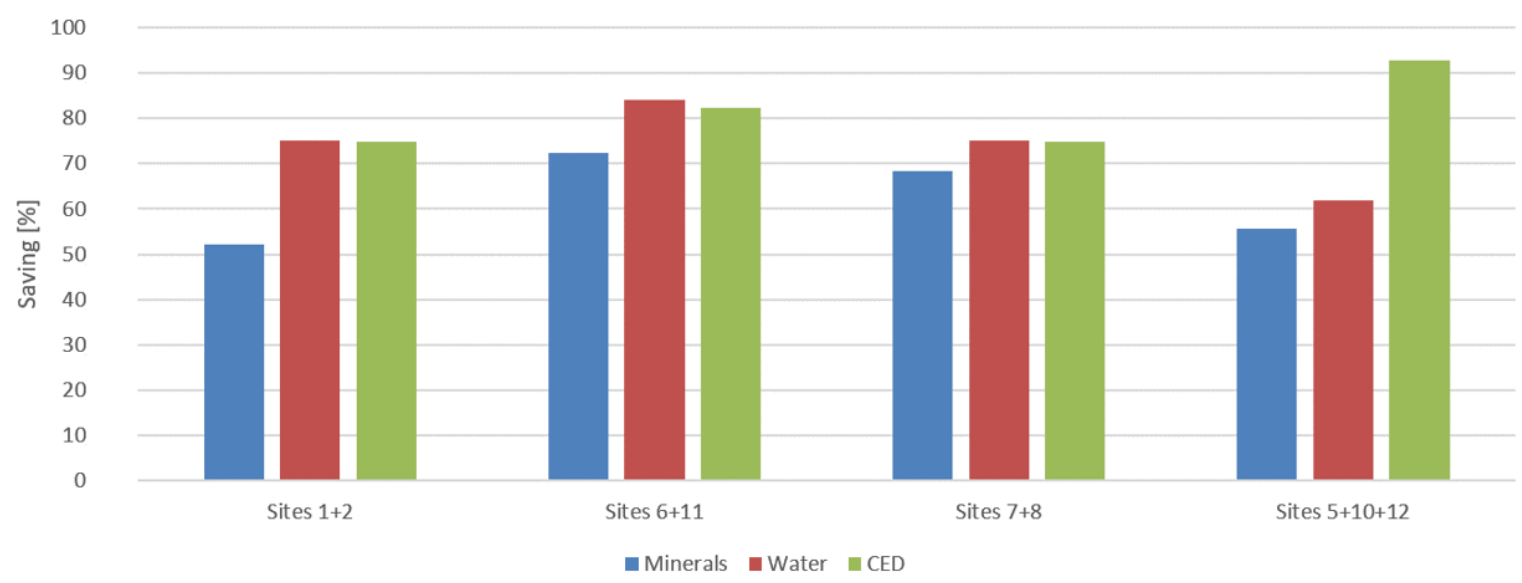

Figure 15. LCA for the merging options regarding raw materials and cumulative energy demand.

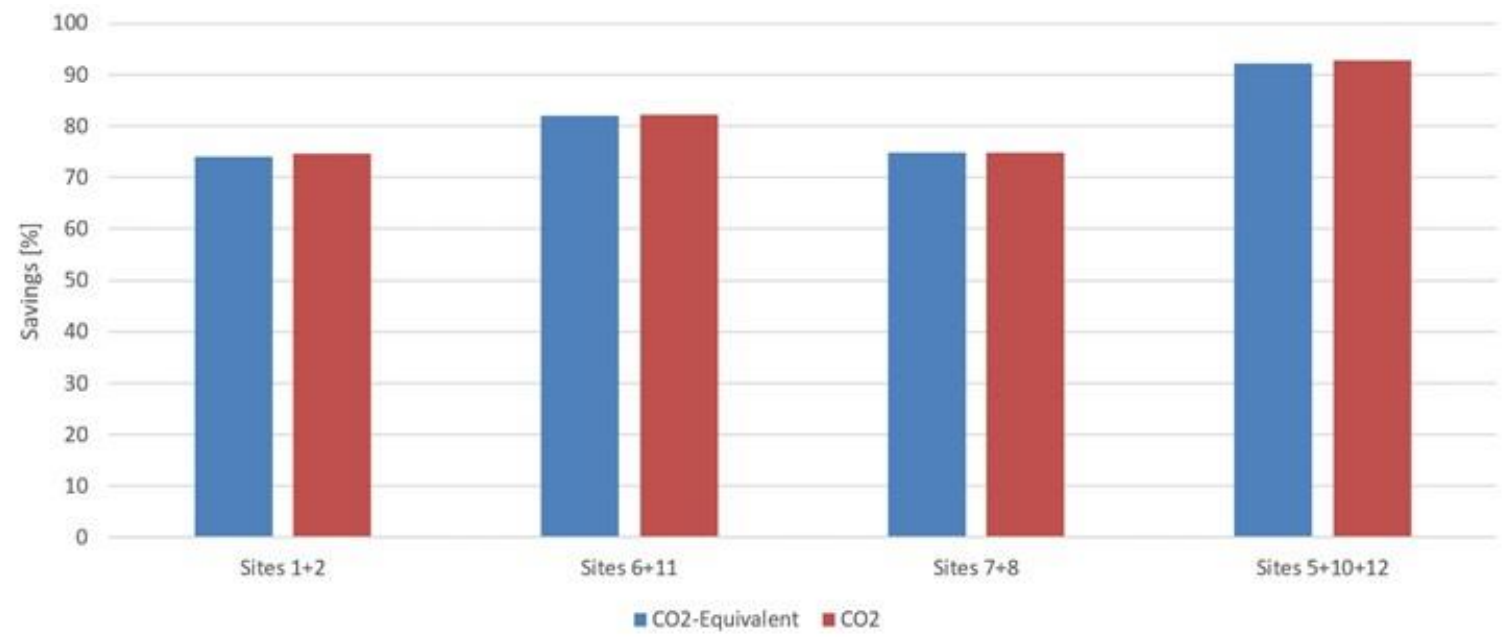

Figure 16. LCA for the merging options regarding the global warming potential.

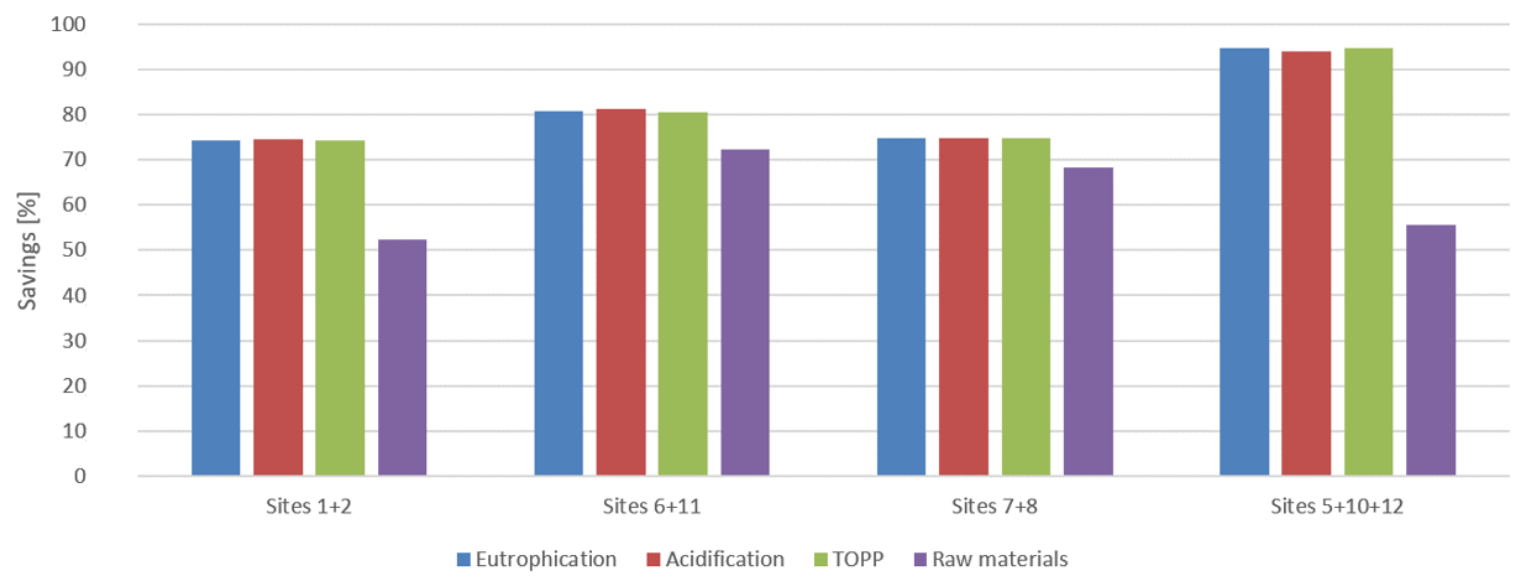

Figure 17. LCA for the merging options regarding the environmental impact categories: eutrophication, acidification potential and TOPP. 
Regarding the resource efficiency exploitation potential caused by site merging, we note a positive pollutant balance for all opencast mines. In all impact categories, the location merging achieves savings in the range of $52 \%$ to $94 \%$.

The savings can be primarily attributed to higher equipment utilization rates and the consequent lower energy demands. The direct environmental pollution is reduced through, for example, the combustion of coal and diesel. Accordingly, the influence of the value pre-chains for the provision of fossil fuels is reduced, which also has a positive impact. There are several reasons for the particularly high resource efficiency exploitation potential by the merging of Sites 5,10 , and 12 . The first is simply the number of sites, i.e., the greater the number of merged opencast mines, the higher the optimization of equipment utilization. The second reason is the significant reduction in the high environmental impact of Site 5. Generally, consideration should be given to the benefits accruing to all parties involved. Alongside the reduction in environmental pollution, the more efficient production and optimization of equipment utilization will also lower costs for mine operators.

\section{Conclusions}

In the framework of the investigation, we have identified institutional, organizational and economical challenges to the environmentally-friendly and socio-efficient mining of aggregate in Vietnam. Established forms of licensing and funding, by which many small companies are granted licenses, have encouraged the plundering of mineral stocks. In an extreme case, this system leads to the fact that the companies are mutually interfering with one another. The majority of the mining operators cannot achieve Best Practice in mining technology or exploratory/pre-processing work because the areas mined are too small to create the needed system of ramps, berms, slopes and benches. The uncontrolled licensing by the supervisory authorities prevents continuous mining and extracting technology. This leads to high extraction losses, since a strictly maximum exploitation is prevented by narrowly designated mining strips, thus preventing extraction of a large share of resources. Therefore, the application of $\mathrm{CP}$ is currently limited, and can only be implemented in certain process steps such as drilling blasting, crushing and sieving as well as hauling and transport.

Due to small-scale nature of mining operations, annual extraction volumes per mine are also small, i.e., less than $50,000 \mathrm{~m}^{3}$ /year against a benchmark average of $300,000 \mathrm{~m}^{3} /$ year. This is insufficient to generate revenues for investment in technology and equipment. Further, the approved quantities suggest a relatively short operating lifetime for each quarry. The mining operators reported major difficulties in getting bank loans. Due to huge discrepancies between the approved design of the operational plan and the practiced mining technology as well as poor supervision, mining operations are highly inefficient. The small operational size can also result in technical overcapacity that hinders the internal flow of materials and finally leads to company bankruptcy. Apart from the fact that the licensing practice hinders continuous mining, under the current system, individual enterprises are forced eventually to cease mining activities when controlled blasting is no longer possible and the mountain valleys become heavily polluted with explosive gases.

This will inevitably lead to market-related adjustments by means of new technologies. In addition, the majority of mining companies are over-mechanized, resulting in the sporadic utilization of machinery due to the low annual subsidies. It should be noted that vehicles were in a good state of repair, in sharp contrast to the poor conditions of the crushing and conveyor systems. The merging of spatially adjacent mines would not only lead to more coordinated planning, but would also lower fuel consumption (diesel and electric power). Eventually, economic necessity will force the Vietnamese aggregate industry to introduce optimal operation sizes. Estimation of the optimal size of mining sites would require an investigation of the entire mining process based on a detailed cost-benefit analysis, which was not part of the present investigation.

Until now, there has been no systematic implementation of cleaner production methods in Vietnam's aggregate mining sector, although there is some scientific discussion on this issue [17]. 
However, there exist considerable potentials for the implementation of $\mathrm{CP}$, particularly at the level of small-scale industrial mining. These are:

- Technical optimization measures aimed at improving the efficiency of resource consumption/production (raw materials, energy, and hazardous substances);

- Technical provisions for improved health and safety;

- Technical measures to reduce environmental impacts (sewage, waste, noise, dust, vibration, exhaust gas, etc.);

- Measures to better handle emergency situations;

- The reduction of land consumption and better rehabilitation of damaged land;

- Compensation for the loss of natural habitats and ecosystem services; and

- The Establishment of implementation and enforcement routines to ensure better control.

The application of $\mathrm{CP}$ to mining is a key part of the process of continuous improvement aimed at raising the efficiency of resource usage and mining operations over the entire lifecycle as well as continuously reducing waste disposal and rehabilitation requirements. Currently, the main focus of the mining companies is on occupational health and safety. Due to the small revenues from the non-efficient operations, environmental protection and monitoring are only implemented to the extent required by law. The aggregate companies practice OHS measures, usually by establishing an internal OHS management system for: (a) the machines and equipment; and (b) mining operations. The results of the questionnaire show that OHS measures generally follow the standard TOP principle as applied in Europe: technical measures-organizational measures-personal protective equipment. However, CP goes much further than this by integrating and implementing a range of well-known concepts of good environmental practice, specifically pollution prevention, waste reduction, recycling and the reuse of waste resources as new products under the Minerals-Energy nexus.

This requires the integration of spatial planning and environmental protection for mines where construction materials are extracted [34]. Mining can become more environmentally-friendly through the development and integration of practices and techniques that reduce the environmental impact. These practices include measures such as reducing water and energy consumption, reducing land degradation and waste production, avoiding soil, water and air pollution [35], the integration of industrial ecology concepts into waste management [36] as well as carrying out successful closure and rehabilitation activities after the end of mining operations. By its very nature, mining is always associated with environmental pollution and emissions, and always entails the consumption of non-renewable resources. For these reasons, there can be no truly "sustainable mining". However, in the case at hand, the merging of adjacent mines can help to reduce the relative environmental impact per functional unit while improving the efficiency in dealing with non-renewable resources. We use the term "responsible mining" to describe such improved mining operations.

At the same time, it is worthwhile considering various options to influence the extent of land take by mining, e.g., by paying closer attention to land use conflicts between mining activities and other land requirements such as settlement development, tourism or landscape conservation. Further, options should be identified regarding material efficiency within construction, settlement and infrastructure policies. The enormous pressure to provide material resources for building forces us to look for new, integrated solutions to make mining more sustainable. While CP optimization strategies can certainly contribute to this, they are not in themselves sufficient without being accompanied by an integrated or nexus approach that links two or more separate aspects. The nexus approach has become quite common over the past years, with scientific literature already clearly defining the Water-Energy-Food nexus and the Water-Soil-Waste nexus. Although the nexus approach has not yet been applied to the mining sector, McLellan (2017) [37] suggests the Minerals-Energy nexus, referring to the competing energy demands in the production and processing of minerals and the demand for minerals in energy technologies. It should be noted that the previously mentioned nexus approaches have a triadic structure, representing the sustainability triangle according to Elkington (1997) [38]. From the 
scientific perspective, minerals are understood to encompass all mineral resources such as metals and aggregates. Legally, coal is also considered a mineral resource, and is taxed as such. In our case, the Minerals-Energy nexus (in analogy to the Water-Energy-Food nexus) refers to aggregates as well as the energy needed for their production, which is partly generated from non-renewable sources. Of course, the nexus also functions in the opposite direction. Minerals (aggregates) have been, and still are, used to build energy producing facilities. From our point of view, LCA is a highly useful tool to assess the links between minerals and energy in aggregate mining, especially as abiotic resource consumption (an indicator for minerals) and cumulative energy demand (an indicator for energy consumption) are assessed jointly.

Supplementary Materials: Available online at http:/ /www.mdpi.com/2071-1050/10/2/xx/s1.

Acknowledgments: The project "Management of mineral resources extraction in Hoa Binh Province-A contribution to sustainable development in Vietnam (MAREX)" was supported by Germany's Federal Ministry of Education and Research, code: NDT.04.GER/15.

Author Contributions: All authors were involved in the design of the paper. Klaus-Dieter Oswald and Wolfgang Riedel coordinated the data collection, conducted the field investigations and contributed substantially through their valuable long-term mining experience to the interpretation of results. Georg Schiller and Tamara Bimesmeier supported and joined the field investigations to link questions of cleaner productions with more general questions of the supply and demand of building materials in the context of urbanization. They provided basic information on mining activities in Hoa Binh Province and on the dynamics of future demand for building materials determined by the material flow analysis of construction activities in Hoa Binh Province and Hanoi. Long Nguyen Khac and Viet Anh Pham Thi supported the background data collection of Vietnamese sources. Andreas Meyer calculated the life-cycle assessment for both variants: (a) the existing situation; and (b) the prognosis of a potential future situation of merged companies. Petra Schneider created the project concept for the MAREX subproject on $\mathrm{CP}$, prepared the environmental assessment, and wrote the paper. Some interim results of the investigation were presented at the International Conference on Environment and Sustainable Development in Mineral Resource Extraction held at the Institute of Environment and Automation in Hanoi from 29 to 30 October 2017.

Conflicts of Interest: The authors declare no conflict of interest.

\section{References}

1. General Statistics Office of Vietnam (GSO). Statistical Handbook of Vietnam; GSO: Hanoi, Vietnam, 2016.

2. Socialist Republic of Vietnam, The Prime Minister. Master Plan on development of Vietnams Construction materials up to 2020. 2008. Available online: http://hethongphapluatvietnam.com/decision-no-1212008-qd-ttg-of-august-29-2008-approving-the-master-plan-on-development-of-vietnams-constructionmaterials-up-to-2020.html (accessed on 05 October 2017).

3. General Statistics Office of Vietnam (GSO). Population Projection for Vietnam 2009-2049; Ministry of Planning and Investment: Hanoi, Vietnam, 2011.

4. Nguyen Van, P.; Nguyen Xuan, Q. Mining status and potential of building materials in Luong Son District, Hoa Binh Province. In Institute of Environment and Automation (IEA)/Leibniz Institute of Ecological Urban and Regional Development (IOER), Proceedings of the International Conference on Environment and Sustainable Development in Mineral Resource Extraction, Hanoi, Vietnam, 29-30 October 2017; Vietnam Academy of Science and Technology Press: Hanoi, Vietnam, 2017; pp. 167-177, ISBN 978-604-913-623-8.

5. Asian Development Bank. Urban Metabolism of Six Asian Cities; Asian Development Bank: Mandaluyong City, Philippines, 2014.

6. Tran Hong, C.; Dong Kim, L.; Tran Binh, M. Recycling of solid waste for crushed sand and unbaked brick production in Luong Son disctrict, Hoa Binh province. In Institute of Environment and Automation (IEA)/Leibniz Institute of Ecological Urban and Regional Development (IOER), Proceedings of the International Conference on Environment and Sustainable Development in Mineral Resource Extraction, Hanoi, Vietnam, 29-30 October 2017; Vietnam Academy of Science and Technology Press: Hanoi, Vietnam, 2017; pp. 92-102, ISBN 978-604-913-623-8.

7. Lockrey, S.; Nguyen, H.; Crossin, E.; Verghese, K. Recycling the construction and demolition waste in Vietnam: Opportunities and challenges in practice. J. Clean. Prod. 2016, 133, 757-766. [CrossRef] 
8. Vietnam Institute for Urban and Rural Planning (VIUP). Construction Master Plan for Hanoi Capital Region to 2020, Vision to 2050, Approval Decision: Số 490/QĐ-TTg ngày 5 May 2008. 2008. Available online: http:/ / www.viup.vn/en/Regional-Planning-pla74-Construction-master-plan-for-Hanoi-capitalregion-to-2020-vision-to-2050-d182.html (accessed on 05 October 2017).

9. International Organization for Standardization. ISO 14040:2006. Environmental Management-Life Cycle Assessment-Principles and Framework; International Organization for Standardization: Geneva, Switzerland, 2006.

10. International Organization for Standardization. ISO 14044:2006. Environmental Management-Life Cycle Assessment-Requirements and Guidelines; International Organization for Standardization: Geneva, Switzerland, 2006.

11. The Organisation for Economic Co-Operation and Development (OECD). Measuring Material Flows and Resource Productivity. 2008. Available online: https://www.oecd.org/environment/indicators-modellingoutlooks/MFA-Guide.pdf (accessed on 27 December 2017).

12. Brunner, P.H.; Rechberger, H. Practical Handbook of Material Flow Analysis; CRC Press LLC: Boca Raton, FL, USA, 2004; ISBN 1566706041.

13. Braungart, M.; McDonough, W. Cradle to Cradle. Remaking the Way We Make Things; North Point Press: New York, NY, USA, 2002.

14. Müller, B.; Albrecht, J.; Linh, L.T.; Schiappacasse, P.; Vu Anh, M.; Wirth, P. Societal and Institutional Interrelations of Aggregates Mining in Vietnam. In Institute of Environment and Automation (IEA)/Leibniz Institute of Ecological Urban and Regional Development (IOER), Proceedings of the International Conference on Environment and Sustainable Development in Mineral Resource Extraction, Hanoi, Vietnam, 29-30 October 2017; Vietnam Academy of Science and Technology Press: Hanoi, Vietnam, 2017; pp. 144-160, ISBN 978-604-913-623-8.

15. Vietnam Institute for Urban and Rural Planning (VIUP). Construction Master Plan for Hoa Binh Province Region to 2020, Approval Decision: 1314/QĐ-UBND. 2012. Available online: http://www.viup.vn/en/ Regional-Planning-pla74-Construction-master-plan-for-Hoa-Binh-province-region-to-2020-d187.html (accessed on 05 October 2017).

16. United Nations Environment Programme (UNEP). Environmental Agreements and Cleaner Production-Questions and Answers; Frequently Asked Questions: Applying Cleaner Production to Facilitate the Implementation of Multilateral Environmental Agreements; United Nations Environment Programme; Division of Technology, Industry \& Economics, In Cooperation with InWEnt: Paris, France, 2006; ISBN 92-807-2717-6.

17. Dong Kim, L.; Tran Hong, C.; Tran Hong, C.; Tran Thi, P.; Pham Thi, V.A. Application of cleaner production in rock exploitation for civil construction in Luong Son district, Hoa Binh province: The chance, challenges and the results achieved. In Institute of Environment and Automation (IEA)/Leibniz Institute of Ecological Urban and Regional Development (IOER), Proceedings of the International Conference on Environment and Sustainable Development in Mineral Resource Extraction, Hanoi, Vietnam, 29-30 October 2017; Vietnam Academy of Science and Technology Press: Hanoi, Vietnam, 2017; pp. 81-91, ISBN 978-604-913-623-8.

18. Nguyen Due, T.; Luu Ngoe, T. The 2010 Mineral's Law-Innovation in Mineral Resources Management in Vietnam. In Institute of Environment and Automation (IEA)/Leibniz Institute of Ecological Urban and Regional Development (IOER), Proceedings of the International Conference on Environment and Sustainable Development in Mineral Resource Extraction, Hanoi, Vietnam, 29-30 October 2017; Vietnam Academy of Science and Technology Press: Hanoi, Vietnam, 2017; pp. 161-166, ISBN 978-604-913-623-8.

19. Schneider, P.; Oswald, K.-D.; Riedel, W.; Meyer, A. Environmental Assessment Approaches to Foster the Implementation of Cleaner Production Strategies in Vietnamese Aggregates Mining. In Institute of Environment and Automation (IEA)/Leibniz Institute of Ecological Urban and Regional Development (IOER), Proceedings of the International Conference on Environment and Sustainable Development in Mineral Resource Extraction, Hanoi, Vietnam, 29-30 October 2017; Vietnam Academy of Science and Technology Press: Hanoi, Vietnam, 2017; pp. 103-112, ISBN 978-604-913-623-8.

20. Clausen, A.; Hoa Vu, H.; Pedrono, M. An evaluation of the environmental impact assessment system in Vietnam: The gap between theory and practice. Environ. Impact Assess. Rev. 2011, 31, 136-143. [CrossRef] 
21. International Council on Mining and Metals (ICMM). Maximizing Value: Guidance on Implementing Materials Stewardship in the Minerals and Metals Value Chain. 2006. Available online: http:/ / www.icmm.com/en-gb / publications / materials-stewardship/maximizing-value-guidanceon-implementing-materials-stewardship-in-the-minerals-and-metals-value-chain (accessed on 6 July 2017).

22. Atherton, J. Resource Efficiency in the Minerals and Metals Sector. In Proceedings of the UNEP/OECD Workshop, Paris, France, 23-25 April 2008; Available online: https://www.oecd.org/env/indicatorsmodelling-outlooks / Atherton.pdf (accessed on 6 July 2017).

23. Schaltegger, S.; Herzig, C.; Kleiber, O.; Klinke, T.; Müller, J. Nachhaltigkeitsmanagement in Unternehmen-Von der Idee zur Praxis: Managementansätze zur Umsetzung von Corporate Social Resposibility und Corporate Sustainability; Bundesministerium für Umwelt, Naturschutz und Reaktorsicherheit: Bonn, Germany, 2007; ISBN 978-3-935630-60-3.

24. International Institute for Sustainability Analysis and Strategy (IINAS). GEMIS-Global Emissions Model for Integrated Systems. 2017. Available online: http:/ /iinas.org/gemis.html (accessed on 6 September 2017).

25. Bare, J.C.; Hofstetter, P.; Pennington, D.W.; De Haes, H.A.U. Midpoints versus endpoints: The sacrifices and benefits. Int. J. Life Cycle Assess. 2000, 5, 319. [CrossRef]

26. Eco-bau Swiss Society of Sustainability in Public Construction. Ratgeber Ökobilanz-Baustoffe. 2017. Available online: http://www.gesundes-haus.ch/baumeister/oekobilanz-baustoffe.html (accessed on 13 October 2017).

27. Korak, J. Technisch-Wirtschaftliche Untersuchung der Transportbetriebsmittel unter besonderer Berücksichtigung der Transportmittel-Kombination Fahrbare Brechanlage-Gurtbandanlage für den Transport der Haufwerke im Engeren Festgestein-Tagebaubereich [Technical-Economic Studies of Transportation Equipment Considering Especially the Combination of Mobile Crusher-Conveyor Systems for the Transportation of Blasted Rock in Narrow Open Pit Areas]. Aachen, NRW: RWTH Aachen. KTBL. Kuratorium für Technik und Bauwesen in der Landwirtschaft e.V. Pflanzenöl [Plant Oil]. Available online: https: / www.ktbl.de (accessed on 16 February 2016).

28. Braun, T.; Hennig, A.; Lottermoser, B.G. The need for sustainable technology diffusion in mining: Achieving the use of belt conveyor systems in the German hard-rock quarrying industry. J. Sustain. Min. 2017, 16, 24-30. [CrossRef]

29. Department of Economic Development, Jobs, Transport and Resources. Code of Practice for Small Quarries; Department of Economic Development, Jobs, Transport and Resources: Victoria, Australia, 2010; ISBN 978-1-74264-198-0 (Print); ISBN 978-1-74264-199-7.

30. Agioutantis, Z.; Maurigiannakis, S.; Athousaki, A. SARMa Sustainable Approach to Aggregates-Sustainable Aggregates Resource Management: Synthesis Report, SEE/A/151/2.4/X. 2011. Available online: http: / / www.sarmaproject.eu/index.php?id=1557 (accessed on 30 December 2017).

31. Agioutantis, Z.; Athousaki, A. SARMa Sustainable Aggregates Resource Management: Recommendations for Socially Acceptable Industry Performance. SEE/A/151/2.4/X. 2011. Available online: http:/ /www. sarmaproject.eu/index.php?id=1557 (accessed on 30 December 2017).

32. Agioutantis, Z.; Athousaki, A. SARMa Sustainable Aggregates Resource Management: Environmentally Friendly Extraction Practices. SEE/A/151/2.4/X. 2011. Available online: http:/ /www.sarmaproject.eu/ index.php?id=1557 (accessed on 30 December 2017).

33. Vietnam Power Group. Vietnam Electricity Annual Report 2016; Vietnam Power Group: Hanoi, Vietnam, 2016.

34. Luu Duc, M.; Ngo Trung, H.; Nguyen Tien, T. The Integration of Spatial Planning and Environmental Protection for Construction Material Mining Areas in Luong Son Disctrict, Hoa Binh Province. In Institute of Environment and Automation (IEA)/Leibniz Institute of Ecological Urban and Regional Development (IOER), Proceedings of the International Conference on Environment and Sustainable Development in Mineral Resource Extraction, Hanoi, Vietnam, 29-30 October 2017; Vietnam Academy of Science and Technology Press: Hanoi, Vietnam, 2017; pp. 178-184, ISBN 978-604-913-623-8.

35. Hilson, G. Pollution prevention and cleaner production in the mining industry: An analysis of current issues. J. Clean. Prod. 2000, 8, 119-126. [CrossRef]

36. Lèbre, E.; Glen, C. Integrating Industrial Ecology Thinking into the Management of Mining Waste. Resources 2015, 4, 765-786. [CrossRef] 
37. McLellan, B.C. The Minerals-Energy Nexus: Past, Present and Future. In Sustainability Through Innovation in Product Life Cycle Design (EcoProduction); Matsumoto, M., Masui, K., Fukushige, S., Kondoh, S., Eds.; Springer: Tokyo, Japan, 2017; pp. 619-631. [CrossRef]

38. Elkington, J. Cannibals with Forks-Triple Bottom Line of 21st Century Business; New Society Publishers: Stoney Creek, CT, USA, 1997. 